\title{
Induction of programmed cell death in Trypanosoma cruzi by Lippia alba essential oils and their major and synergistic terpenes (citral, limonene and caryophyllene oxide)
}

\author{
Érika Marcela Moreno ${ }^{1}$, Sandra Milena Leal ${ }^{1,2}$, Elena E. Stashenko ${ }^{3}$ and Liliana Torcoroma García ${ }^{1 *}$ (0)
}

\begin{abstract}
Background: Chagas Disease caused by Trypanosoma cruzi infection, is one of the most important neglected tropical diseases (NTD), without an effective therapy for the successful parasite eradication or for the blocking of the disease's progression, in its advanced stages. Due to their low toxicity, wide pharmacologic spectrum, and potential synergies, medicinal plants as Lippia alba, offer a promising reserve of bioactive molecules. The principal goal of this work is to characterize the inhibitory properties and cellular effects of the Citral and Carvone L. alba chemotype essential oils (EOs) and their main bioactive terpenes (and the synergies among them) on T. cruzi forms.

Methods: Twelve L. alba EOs, produced under diverse environmental conditions, were extracted by microwave assisted hydrodistillation, and chemically characterized using gas chromatography coupled mass spectrometry. Trypanocidal activity and cytotoxicity were determined for each oil, and their major compounds, on epimastigotes (Epi), trypomastigotes (Tryp), amastigotes (Amas), and Vero cells. Pharmacologic interactions were defined by a matrix of combinations among the most trypanocidal terpenes (limonene, carvone; citral and caryophyllene oxide). The treated cell phenotype was assessed by fluorescent and optic microscopy, flow cytometry, and DNA electrophoresis assays.

Results: The L. alba EOs displayed significant differences in their chemical composition and trypanocidal performance $(p=0.0001)$. Citral chemotype oils were more trypanocidal than Carvone EOs, with Inhibitory Concentration $50\left(\mathrm{IC}_{50}\right)$ of $14 \pm 1.5 \mu \mathrm{g} / \mathrm{mL}, 22 \pm 1.4 \mu \mathrm{g} / \mathrm{mL}$ and $74 \pm 4.4 \mu \mathrm{g} / \mathrm{mL}$, on Epi, Tryp and Amas, respectively. Limonene exhibited synergistic interaction with citral, caryophyllene oxide and Benznidazole (decreasing by 17 times its $I_{50}$ ) and was the most effective and selective treatment. The cellular analysis suggested that these oils or their bioactive terpenes (citral, caryophyllene oxide and limonene) could be inducing T. cruzi cell death by an apoptotic-like mechanism.

Conclusions: EOs extracted from L. alba Citral chemotype demonstrated significant trypanocidal activity on the three forms of T. cruzi studied, and their composition and trypanocidal performance were influenced by production parameters. Citral, caryophyllene oxide, and limonene showed a possible induction of an apoptotic-like phenotype. The best selective anti-T. cruzi activity was achieved by limonene, the effects of which were also synergic with citral, caryophyllene oxide and benznidazole.
\end{abstract}

Keywords: Lippia alba, Essential oils, Citral, Caryophyllene oxide, Limonene, Synergy, Trypanosoma cruzi

\footnotetext{
* Correspondence: I.torcoroma@udes.edu.co

${ }^{1}$ Infectious Disease Research Program, Universidad de Santander, 680006

Bucaramanga, Colombia

Full list of author information is available at the end of the article
}

(c) The Author(s). 2018 Open Access This article is distributed under the terms of the Creative Commons Attribution 4.0 International License (http://creativecommons.org/licenses/by/4.0/), which permits unrestricted use, distribution, and reproduction in any medium, provided you give appropriate credit to the original author(s) and the source, provide a link to the Creative Commons license, and indicate if changes were made. The Creative Commons Public Domain Dedication waiver (http://creativecommons.org/publicdomain/zero/1.0/) applies to the data made available in this article, unless otherwise stated. 


\section{Background}

Chagas Disease is one of the most important Neglected Tropical Diseases (NTDs) worldwide, and is one of the most relevant public health problems in Latin America. This infection, caused by the hemoflagellated protozoan Trypanosoma cruzi, currently affects an estimated 7 million people in the world, with around 99\% of all registered cases occurring in Central and South American countries [1]. The global costs of this disease are calculated at approximately USD $\$ 7.19$ billion per year [2], with regional economic losses of almost US \$1.2 billion, annually [3]. In Colombia, the prevalence of this trypanosomiasis is estimated to be within a range of 700,000 - 1,200,000 cases, with more than $8,000,000$ persons at risk [4].

In regions where the condition is endemic, disease-control efforts principally centered on preventing or reducing the $T$. cruzi transmission cycle by vector eradication and massive blood donation screening [5]. However, bigger challenges remain; in particular, those associated with the changing epidemiological profile of the infection (diversity of vectors, reservoirs, and modes of transmission), being the most significant problem, the lack of effective therapies to cure the T. cruzi infection or to prevent the progression of the disease, principally in advanced stages.

At present, the conventional Chagas Disease treatments are etiologic, and are comprised of only two possible options, Nifurtimox (NFX) (Lampit ${ }^{\oplus}$, Bayer) and Benznidazole (BNZ) (Rochagan ${ }^{\odot}$ in Brazil and Radanil $^{\bullet}$ in Argentina, Roche). These two treatments have remained the standard since their introduction into clinical therapy more than 40 years ago [6]. As disadvantages, these treatments are highly toxic (often accompanied by serious side effects like digestive intolerance, severe anorexia and neurological disorders) [7]; involve prolonged treatment times; and demonstrate variable trypanocidal effectiveness in acute stage (with about $80 \%$ being associated with natural resistance). They also display limited efficacy in the late phase of the infection (in which the benefits of these therapies have not clearly defined) $[8,9]$.

In general, these conventional therapies do not take into account the complex cascade of cellular events leading to Chagasic cardiomyopathy, which are not only associated with the parasite's presence, but also involve exacerbated and persistent immune response (with cellular and neuronal damage) [10, 11]. These latter factors are those which govern the microvasculopathy and cardiac failure associated with the condition [10, 11].

In this regard, the research and development of new alternative therapies for Chagas Disease remain pressing concerns. New pharmacological approaches should be more efficient and selective, seeking complete parasite elimination, but with adequate modulation of the host immune response and limitation of cellular damage [11]. To this end, in the last two decades, intensive research has been focused on the study of the properties of whole extracts or compounds isolated from plants or synthesized based on natural prototypes, which have shown promising results against parasite infections [12, 13].

Essential oils (EOs) extracted from aromatic plants and their main components have been described as broad-spectrum antimicrobial agents [14], with significant anthelmintic and antiprotozoal activity $[15,16]$. Some terpenes of these oils such as citral (Lippia alba and Cymbopogon citratus), caryophyllene oxide (Aframomum sceptrum, Achillea millefolium, and Piper var brachypodon), and limonene (L. origanoides and L. pedunculosa) have demonstrated efficient trypanocidal activity on extra and intracellular forms of T. cruzi [17-20]. In addition, these terpenes have been found to exhibit other interesting biological properties, such as being anti-inflammatory immunomodulators, selective antioxidants, and cytoprotectors [21-24]. The presence of citral, caryophyllene and limonene has been identified in EOs isolated from two chemotypes (Citral and Carvone) of the aromatic shrub Lippia alba (Miller) N.E. Brown (Verbenaceae), that grows in the Colombian province of Santander [21, 25]. L. alba represents the seventh species most cited in traditional Brazilian medicine [26]. The "healers" use their leaves as an infusion to treat health problems such as hypertension, digestive, colds and local wound healing [27, 28]. In the state of Boyacá, Colombia, it is frequently used as an analgesic, for digestive (diarrhea, stomach pain) and respiratory problems (flu and cough) [29]. Previous screening studies with these oils evidenced selective inhibition and cytotoxicity against trypanosomatid parasites, in vitro [30]. Taking into consideration their numerous functions, L. alba EOs and their bioactive terpenes are a promising platform for development of holistic therapies to combat Chagas Disease. This kind of approach could allow for a selective eradication of the parasite, with less toxicity (even with chemoprotection), and for controlling the host immune response, through a possible synergistic interaction of the compounds involved [22, 31, 32].

The principal goal of this work is to characterize the inhibitory properties and cellular effects of the Citral and Carvone L. alba chemotype EOs and their main bioactive terpenes on $T$. cruzi epimastigotes, trypomastigotes, and amastigotes cyclic forms. The $\mathrm{IC}_{50}$ was determined for each of these compounds, and possible pharmacologic interactions were defined by a matrix of combinations of the trypanocidal compounds (from Carvone chemotype: limonene and carvone; and from Citral chemotype: citral and caryophyllene oxide). The phenotype of the parasites and mammal cells treated with EOs or terpenes was followed by fluorescent and optic microscopy, flow cytometry, and DNA electrophoresis assays. 


\section{Methods}

\section{Plant material}

In this study, specimens of the Citral and Carvone chemotypes of Lippia alba (Miller) N. E. Brown (Verbenaceae) were planted in the National Research Center for Agroindustrialization of Aromatic Medical and Tropical species (CENIVAM, in Spanish) located in Bucaramanga, Santander, Colombia, at an altitude of $960 \mathrm{~m}$ above sea level. The formal identification of the plant specimens used in this study was provided by Prof. Jorge Luis Fernández Alonso and the vouchers were deposited at the Colombian National Herbarium (Universidad Nacional de Colombia) under Herbarium Codes COL480750 and COL512077, for Carvone and Citral chemotypes of L. alba, respectively. A range of environmental and production conditions were used in order to produce 76 EOs with possible diversity in their main compounds. In this regard, the vegetal material was grown, collected, and extracted under the following factors. 1) season: defined as dry (January to March, $26.3{ }^{\circ} \mathrm{C}$ temperature, with $68.9 \%$ relative humidity, and $1.05 \mathrm{~mm}$ /day precipitation) and rainy (April to November, mean temperature of $24.5{ }^{\circ} \mathrm{C}$, relative humidity of $81.3 \%$, and $4.13 \mathrm{~mm}$ of daily precipitation); 2) L. alba chemotypes (53 from Carvone and 23 from Citral); 3) part of plant harvested (root, stem, fresh and mature leaves, and flowers); 4) vegetal material conditions (fresh and dry); and 5) extraction time (from 30 to $90 \mathrm{~min}$ ).

\section{Essential oils extraction and characterization}

The oil extraction was performed by microwave-assisted hydrodistillation (MWHD), as described elsewhere [25, 29]. Briefly, a domestic microwave oven (Kendo, $2.45 \mathrm{GHz}$, $800 \mathrm{~W}$ ) was modified with a side orifice through which an external Dean-Stark trap joined a round flask that contained the plant material $(100 \mathrm{~g})$ and water $(0.5 \mathrm{~L})$, inside the oven. Three $15 \mathrm{~min}$ heating periods at full power were used to perform the hydrodistillation. The Dean-Stark trap permitted to decant the essential oil from the condensate. A gas chromatograph GC 7890 (Agilent Technologies, AT, Palo Alto, CA, U.S.A.) coupled to a mass selective detector MSD 5975C (AT, Palo Alto, CA, U.S.A.), using electron impact ionization (EI, $70 \mathrm{eV}$ ) was used for essential oil characterization. This system included a split/splitless injector (1:30 split ratio), and a MS-ChemStation G1701-DA data system, with the WILEY, NIST and QUADLIB 2007 spectral libraries. For their GC-MS assays, individual essential oil samples $(50 \mu \mathrm{L})$ were mixed with $n$-tetradecane ( $2 \mu \mathrm{L}$, internal standard) and diluted with dichloromethane to a final volume of $1.0 \mathrm{~mL}$. Helium (99.9995\%) was used as the carrier gas, with $155 \mathrm{kPa}$ column head pressure and $27 \mathrm{~cm} \mathrm{~s}^{-1}$ linear velocity ( $1 \mathrm{~mL}$ minute-1, at constant flow), in two columns of different polarities (DB-5MS and DB-WAX from J\&W Scientific, USA). The GC oven temperature was programmed from $50{ }^{\circ} \mathrm{C}(5 \mathrm{~min})$ to $150{ }^{\circ} \mathrm{C}$ (2 min) at $5{ }^{\circ} \mathrm{C} \min ^{-1}$, then to $230{ }^{\circ} \mathrm{C}(10 \mathrm{~min})$ at $5{ }^{\circ} \mathrm{C} \min ^{-1}$. When the DB-5MS column was used, a final heating to $275{ }^{\circ} \mathrm{C}(15 \mathrm{~min})$ at $10{ }^{\circ} \mathrm{C} \mathrm{min}^{-1}$ was added. The temperatures of the injection port, ionization chamber and of the transfer line were set at 250,230 and $285{ }^{\circ} \mathrm{C}$, respectively. For the polar DB-WAX column, the transfer line temperature was set at $230{ }^{\circ} \mathrm{C}$. Mass spectra and reconstructed (total) ion chromatograms were obtained by automatic scanning in the mass range $m / z 30-400$ at 4.5 scan $\mathrm{s}^{-1}$. Compound relative abundances were calculated from the chromatographic area of profiles obtained with an AT 7890 gas chromatograph provided with flame ionization detection (FID, $250{ }^{\circ} \mathrm{C}$ ). The chromatographic columns, carrier gas and oven temperature programs employed in GC-FID analysis were the same as described previously for the GC-MS system. The EO compounds were identified using mass spectra and linear retention indices relative to $\mathrm{C}_{8}-\mathrm{C}_{32}$ n-alkanes [33]. Several terpenoid standard compounds, such as limonene, carvone, geranial, geraniol, $\beta$-caryophyllene, and $\beta$-caryophyllene oxide, obtained from Sigma-Aldrich (St. Louis, MO, U.S.A., with purities above 98\%) were used. The extracted EOs were preserved at $4{ }^{\circ} \mathrm{C}$ and protected from light before GC-MS and cellular analysis. Finally, the 76 EOs were arranged into 12 groups, according to the significant differences in the percentages of their major terpenes and one oil of each group was arbitrarily selected for further biological analysis, comprising six EOs from Citral chemotype (A13, A20, A23, A24, A25, and A28), and six from the Carvone chemotype (B7, B16, B37, 2B8, 2B18, and 2B19).

\section{Terpenes and drugs}

The terpenes $\mathrm{S}(+)$ carvone, D (+) limonene, (-) caryophyllene oxide, and citral were purchased from Sigma-Aldrich (St. Louis, MO). The reference medication BNZ (Radanil ${ }^{\oplus}$, Roche) was donated by Santander's State Secretary of Health, and purified by Dr. Leonor Yamile Vargas, from the Environmental Chemistry Program at Universidad Santo Tomás de Aquino (Bucaramanga). Concentrations ranging from 1.85 to $50 \mu \mathrm{g} / \mathrm{mL}$ were used for epimastigote (Epi) and amastigote (Amas) assays and 0.39 to $3.12 \mu \mathrm{g} / \mathrm{mL}$ for trypomastigote (Tryp) assays. The oils (at a density of $0.9 \mathrm{~g} / \mathrm{mL}$ ) and terpene stock solutions were prepared in dimethyl-sulfoxide (DMSO, Sigma-Aldrich (St. Louis, MO)), to get a $10 \%$ $(v / v)$ solution, without exceeding a DMSO final concentration of $0.1 \%$, in any solution. Working solutions (3.7 to $300 \mu \mathrm{g} / \mathrm{mL}$ ) were diluted immediately prior to use with Liver Infusion Tryptose (LIT, Becton Dickinson, FL, USA) media and Dulbecco's Modified Eagle's Medium (DMEM, Life Technology, CA, USA) for $T$. cruzi cells and Vero lineage, respectively. 


\section{Cell cultures}

Vero lineage derived from African Green Monkey Kidney (Vero, ATCC CCL-81) was used for selectivity index determination and for Tryp and Amas production. These cells were grown on DMEM (Life Technology, CA, USA) media, pH: 7.4; supplemented with $10 \%$ of inactivated Fetal Bovine Serum (FBSi), $1000 \mathrm{U} / \mathrm{mL}$ of penicillin, and $100 \mu \mathrm{g} / \mathrm{mL}$ of streptomycin; and incubated at $37{ }^{\circ} \mathrm{C}$ with $90 \%$ humidity and a $5 \% \mathrm{CO}_{2}$ atmosphere. Epi of T. cruzi I (TcI) SYLVIO-X10 strain, were donated by Dr. Marcos López-Casillas, from Fundación Cardiovascular de Colombia and grown in LIT medium (Merck) supplemented with $10 \% \mathrm{FBSi}$, and incubated at $28{ }^{\circ} \mathrm{C}$. The Trypomastigotes Derived from Cells (TDC) were obtained by infection of a confluent monolayer of Vero cells with 12 day-old stationary growth phase Epi and incubated under the same conditions described above for Vero cells.

\section{Cytotoxic activity on Vero cells}

Vero cells $\left(3 \times 10^{5} \mathrm{cel} / \mathrm{mL}\right)$ were incubated at $37{ }^{\circ} \mathrm{C}$ in a $5 \% \mathrm{CO}_{2}$ atmosphere and at $95 \%$ humidity for $24 \mathrm{~h}$ to ensure the formation of a confluent monolayer. After this time, the cells were treated with the EOs or their terpenes in four different concentrations (11.1, 33.3, 100, and $300 \mu \mathrm{g} / \mathrm{mL}$ ). Thereafter, the lineages were incubated for $70 \mathrm{~h}$ at $37{ }^{\circ} \mathrm{C}$ in a $5 \% \mathrm{CO}_{2}$ atmosphere and re-incubated 2 more hours with WST-1 (Roche, Mannheim, Germany), after which Optical Density (OD) measurements were analyzed by spectrophotometry. The cytotoxicity percentage was calculated using $\left[\left(\mathrm{OD}_{450 \mathrm{~nm}}\right.\right.$ Control - $\mathrm{OD}_{450 \mathrm{~nm}}$ treatment) $/ \mathrm{OD}_{450 \mathrm{~nm}}$ treatment)] $\times$ 100. The results were expressed as Cytotoxic Concentration $50\left(\mathrm{CC}_{50}\right)$.

\section{Anti-parasitic activity on $T$. cruzi}

T. cruzi Epi $\left(5 \times 10^{5} \mathrm{Epi} / \mathrm{mL}\right)$ and TDC $\left(5 \times 10^{5}\right.$ cells $\left./ \mathrm{mL}\right)$ in the exponential growth phase were plated in a 96-well standard microplate in LIT medium (at $28{ }^{\circ} \mathrm{C}$ ) and in D-MEM medium (at $37{ }^{\circ} \mathrm{C}$ in a $5 \% \mathrm{CO}_{2}$ atmosphere), respectively. Both cultures were supplemented with $10 \% \mathrm{FBSi}$. For the trypanocidal assays, the EOs or their terpenes were added at varying concentrations (3.7 to $100 \mu \mathrm{g} / \mathrm{mL}$ ) and incubated at the same culture conditions for 72 (Epi) or $24 \mathrm{~h}$ (Tryp). The growth inhibition was estimated by light microscopy through a differential count using the Trypan Blue (Gibco) dye exclusion technique. The results were expressed in terms of Inhibitory Concentration $50\left(\mathrm{IC}_{50}\right)$ or the concentration at which parasite growth is inhibited by $50 \%$. For Amas assays, a monolayer of Vero cells $\left(3 \times 10^{5} \mathrm{cel} / \mathrm{mL}\right)$ was infected with TDC in a 1:3 cell:parasite ratio and incubated for $24 \mathrm{~h}$ until Amas development occurred. Then, these intracellular forms were exposed for $120 \mathrm{~h}$ to EOs or terpenes in a treatment applied in two doses (at 0 and $48 \mathrm{~h}$ ), under the same conditions described above. Growth inhibition analysis was assessed in Giemsa-stained films using light microscopy to determine the infected and uninfected cell percentage in a total of 300 cells. Cells without treatment and those treated with BNZ were used as negative and positive controls, respectively.

\section{Pharmacological interaction among terpenes on $T$. cruzi}

A matrix of pharmacological interactions between limonene (the most selective terpene) and the other major EO terpenes was created for the three cyclic forms of T. cruzi, using the fixed-ratio isobologram method, as described previously by Fivelman et al. [34] with some modifications (Table 1). In the interaction matrix, the estimated $\mathrm{IC}_{50}$ for each terpene was used as fixed-value for the combinations. In addition, a mixture of limonene and BNZ was also evaluated.

The susceptibility evaluation was performed following the protocol described above for in vitro anti-parasitic activity. The Fractional Inhibitory Concentration (FIC) was calculated by: (Compound $\mathrm{X}(\mathrm{FIC})=$ Compound $\mathrm{X}\left(\mathrm{IC}_{50}\right)$ in combination) / (Compound $\mathrm{X}\left(\mathrm{IC}_{50}\right)$ alone); and the sum of FIC $(\Sigma F I C)$ was determined by: $\Sigma F I C=$ Compound $\mathrm{X}(\mathrm{FIC})+$ Compound Y (FIC). In this manner, synergistic, antagonist, or additive interactions were defined by $\overline{\mathrm{X}}^{\Sigma \mathrm{CIF}}<1, \overline{\mathrm{X}}^{\Sigma \mathrm{CIF}}$ $>1$ or $\overline{\mathrm{X}}^{\Sigma \mathrm{CIF}}=1$, respectively [31].

\section{Analysis of cell death}

The death phenotype was analyzed by optical and fluorescent microscopy using phase contrast (fluorescence microscopy, Nikon Eclipse Ni). The cell morphology in Epi treated with two doses of the $\mathrm{IC}_{50}\left(2 \mathrm{xIC}_{50}\right)$, was examined by the 4 ;6diamidino-2, phenylindole probe (DAPI, $1 \mu \mathrm{g} / \mathrm{mL}$, Sigma Aldrich) and a TUNEL assay (Molecular Probes, Invitrogen) for DNA fragmentation using a Terminal desoxynucleotidyl Transferase (TdT) label with d-UTP fluorescein. Determination of an oligonucleosomal-DNA ladder in treated parasites was also evaluated through DNA gel electrophoresis. Evaluation of the mitochondrial potential membrane in living parasites was performed with MitoTracker Red CMXRos (579 nm/599 nm emission/excitation wavelength) [35]. As a positive and negative apoptosis control, a 15 day-old

Table 1 Interaction matrix among terpenes

\begin{tabular}{lll}
\hline Combination ID Number & Limonene (Compound X) & Compound $Y$ \\
\hline 1 & 0.0 & $8 \times I C_{50}$ \\
2 & $1 / 2 C_{50}$ & $4 \times I C_{50}$ \\
3 & $I C_{50}$ & $2 \times I C_{50}$ \\
4 & $2 \times I C_{50}$ & $I C_{50}$ \\
5 & $4 \times I C_{50}$ & $1 / 2 \mid C_{50}$ \\
6 & $8 \times I C_{50}$ & 0.0 \\
\hline
\end{tabular}

$\mathcal{C}_{50}$ Inhibitory Concentration 50, $x$ Number of times 
Epi culture and an untreated fresh parasite culture were used, respectively.

\section{Flow cytometry analysis}

For cell death characterization, an Annexin V/Dead with SYTOX $^{\oplus}$ Green (Molecular Probes, Invitrogen) kit was used following the procedure specified in the manufacturer's instructions. The phosphatidylserine externalization was determined by employing a recombinant Annexin V conjugated to the Orange Fluorescent phycobiliprotein R-PE, and to the necrotic cells using SYTOX ${ }^{\mathrm{TM}}$ Green nucleic acid stain. Briefly, $1 \times 10^{6}$ Epi per mL were treated with $2 \mathrm{xIC}_{50}$ for $48 \mathrm{~h}$, washed, and suspended in $1 \mathrm{X}$ Annexin-Binding Buffer. Next, R-PE Annexin V and SYTOX ${ }^{\odot}$ Green Stain were added and incubated at $37{ }^{\circ} \mathrm{C}, 5 \% \mathrm{CO}_{2}$, and $95 \%$ humidity, and analyzed in a FACSCanto II Flow Cytometer (provided by Dr. Marcos López from Fundación Cardiovascular de Colombia), with $488 \mathrm{~nm} / 575 \mathrm{~nm}$ Excitation/Emission filters for R-PE and $503 \mathrm{~nm} / 524 \mathrm{~nm}$ Excitation/Emission filters for SYTOX.

\section{Statistical analysis}

Each treatment was tested in triplicate in three independent assays. The $\mathrm{IC}_{50}$ and $\mathrm{CC}_{50}$ were calculated by sigmoidal regression using the statistical software Msxlfit $^{\mathrm{TM}}$ (ID Business Solution). The cytotoxicity analysis and statistically-significant difference determinations were performed using a Welch's test for analysis of variances using SPSS 15.0 Software (IBM). Multiple comparison analysis was accomplished using a Tukey test with a $95 \%$ confidence level.

\section{Results}

Chemical composition and trypanocidal activity of L. alba EOs This work studied the trypanocidal properties of 12 EOs isolated from Citral and Carvone $L$. alba chemotypes produced under an array of standardized conditions for planting, collecting and extracting of the vegetal material. A typical chromatographic profile for each chemotype essential oil, obtained by mass spectra and linear retention indices, is showed in Fig. 1a and b, for Carvone and Citral oils, respectively. The corresponding peak assignment of these chromatograms are listed in Table 2.

All the EOs presented diversity in their chemical composition, and this variety also appeared as significant differences in their trypanocidal performance on the three cyclic forms of the parasite (Epi: $\mathrm{F}=1320.080 ; p=0.000$; Tryp: $\mathrm{F}=628.786 ; p=0.000$; Amas: $\mathrm{F}=853.422 ; p=0.000$ ) (Tables 3 and 4, Fig. 2a).

The best trypanocidal performance was observed in oils isolated from Citral chemotype plants, with $\mathrm{IC}_{50}$ values of $14 \pm 1.5,22 \pm 1.4$, and $74 \pm 4.4 \mu \mathrm{g} / \mathrm{mL}$ on Epi, Tryp, and Amas, respectively $(p<0.05)$. Among these, the two lowest $\mathrm{IC}_{50}$ achieved were by A20 $(9 \pm 1.2$ and $13.9 \pm 0.9 \mu \mathrm{g} / \mathrm{mL}$, on Epi and Tryp, respectively, $p<0.05)$ and A23 $(8 \pm 1.3$ and $17 \pm 1.3 \mu \mathrm{g} / \mathrm{mL}$, on Epi and Tryp, respectively, $p<0.05$ ) (Table 3 , Fig. $2 \mathrm{a}$ ). However, these oils also displayed a low selectivity, with high toxicity levels on Vero cells (A20: $\mathrm{CC}_{50}=66 \pm 5.9 \mu \mathrm{g} / \mathrm{mL}$; A23: $\mathrm{CC}_{50}=51 \pm 6.2 \mu \mathrm{g} / \mathrm{mL}$ ). Alternatively, oil A13 exhibited a significant level of anti-T. cruzi activity on the three cyclic forms (with $\mathrm{IC}_{50}$ of $17 \pm 1.7 \mu \mathrm{g} / \mathrm{mL},(\mathrm{SI}=7)$; $\mathrm{IC}_{50} 21 \pm$ $1.6 \mu \mathrm{g} / \mathrm{mL},(\mathrm{SI}=5.7)$; and $\mathrm{IC}_{50} 88 \pm 5.4 \mu \mathrm{g} / \mathrm{mL}(\mathrm{SI}=1.4)$, on Epi, Tryp, and Amas, respectively); high cell death percentages $(\mathrm{CDP}) \quad($ Epi $=85 \pm 1.7 \%$; Tryp $=100 \%$; Amas $=57 \pm$ $3.1 \%$; $p<0.05)$, at $100 \mu \mathrm{g} / \mathrm{mL}$; and low toxic effect on mammal cells $\left(\mathrm{CC}_{50} 120 \pm 10 \mu \mathrm{g} / \mathrm{mL}\right)$ (Table 3, Fig. 2a).

In contrast, EOs extracted from Carvone chemotype plants showed higher mean $\mathrm{IC}_{50}$ values $(88 \pm 3.7,45 \pm$ 2.5 , and $>150 \mu \mathrm{g} / \mathrm{mL}$ on Epi, Tryp, and Amas, respectively (Table 4)), with a CDP under $60 \%$, even at high concentrations $(100 \mu \mathrm{g} / \mathrm{mL})$, in both Epi (mean CDP of $56 \pm 2.3 \%$ ) and Tryp (mean CDP of $81 \pm 3.1 \%$ ) forms (Table 4). Among Carvone chemotype oils, the best trypanocidal activity was demonstrated by $\mathrm{B} 7$ with $\mathrm{IC}_{50} 81 \pm$ $2.4 \mu \mathrm{g} / \mathrm{mL}, \mathrm{SI}=2.5$, and a CDP of $60.1 \%$ on Epi forms; and $\mathrm{IC}_{50} 37 \pm 2.1 \mu \mathrm{g} / \mathrm{mL}, \mathrm{SI}=5.5$, and a CDP of $84.5 \%$, on Tryp stages $(p<0.05)$ (Table 4 , Fig. $2 \mathrm{a})$. On T. cruzi replicative intracellular forms, none of the Carvone oils demonstrated significant activity (mean $\mathrm{IC}_{50}>150 \mu \mathrm{g} / \mathrm{mL}$; mean CDP $21 \pm 4.4 \%$ ). Nevertheless, on host cells (Vero) these EOs exhibited lower cytotoxicity (mean $\mathrm{CC}_{50}$ of $200 \pm 11 \mu \mathrm{g} / \mathrm{mL}$ ) than Citral oils (mean $\mathrm{CC}_{50}$ of $87 \pm$ $8.3 \mu \mathrm{g} / \mathrm{mL}$ ) (Table 4, Fig. 2a).

\section{Trypanocidal activity of $L$. alba Terpenes}

For further studies using individual compounds, four of the major terpenes were selected from the L. alba EOs from both chemotypes, Citral (citral and (-) caryophyllene oxide) and Carvone (D (+) limonene and $\mathrm{S}(+)$ carvone). Table 5 presents the $\mathrm{IC}_{50}$ values obtained on the three studied parasitic forms and the $\mathrm{CC}_{50}$ values estimated on Vero cells.

Among the studied terpenes, D (+) limonene exhibited the best $\mathrm{IC}_{50}$ on Tryp $\left(\mathrm{IC}_{50} 9 \pm 0.8 \mu \mathrm{g} / \mathrm{mL}, \mathrm{SI}=32.8, p<0.05\right)$, and Amas $\left(\mathrm{IC}_{50} 29 \pm 0.7 \mu \mathrm{g} / \mathrm{mL}, \mathrm{SI}=10.3, p<0.05\right)$ forms, (Table 5, Fig. 2b), with the most selective and the least toxic performance on mammal cells $\left(\mathrm{CC}_{50} 297 \pm 2.4 \mu \mathrm{g} / \mathrm{mL}\right.$, and $\mathrm{SI}=7.1, p<0.05)$, with a $\mathrm{CC}_{50}$ even lower than the reference drug (BNZ: $\mathrm{CC}_{50} 139 \pm 2.3 \mu \mathrm{g} / \mathrm{mL}$ ). At the other end of the spectrum, $\mathrm{S}(+)$ carvone constituted the terpene with the worst trypanocidal activity on all evolutionary T. cruzi forms (Epi: $\mathrm{IC}_{50} 177 \pm 7.9 \mu \mathrm{g} / \mathrm{mL}$, and SI = 1.4; Tryp: $\mathrm{IC}_{50} 124 \pm$ $7.8 \mu \mathrm{g} / \mathrm{mL}$, and $\mathrm{SI}=1.9$; Amas: $\mathrm{IC}_{50}>100 \mu \mathrm{g} / \mathrm{mL}$ ) (Table 5). It is worth pointing out that all the terpenoid fractions, except carvone, were able to induce significant cell death on extracellular forms of the parasite at $50 \mu \mathrm{g} / \mathrm{mL}$ (Epi: CDP $=$ $66 \pm 1.9 \%$; Tryp: CDP $=90 \pm 1.2 \%, p<0.05)$ with caryophyllene oxide being the terpene with the highest rate of death on Epi (78 $\pm 2.3 \%)$, and Tryp (98 $\pm 0.5 \%, p<0.05)$. 


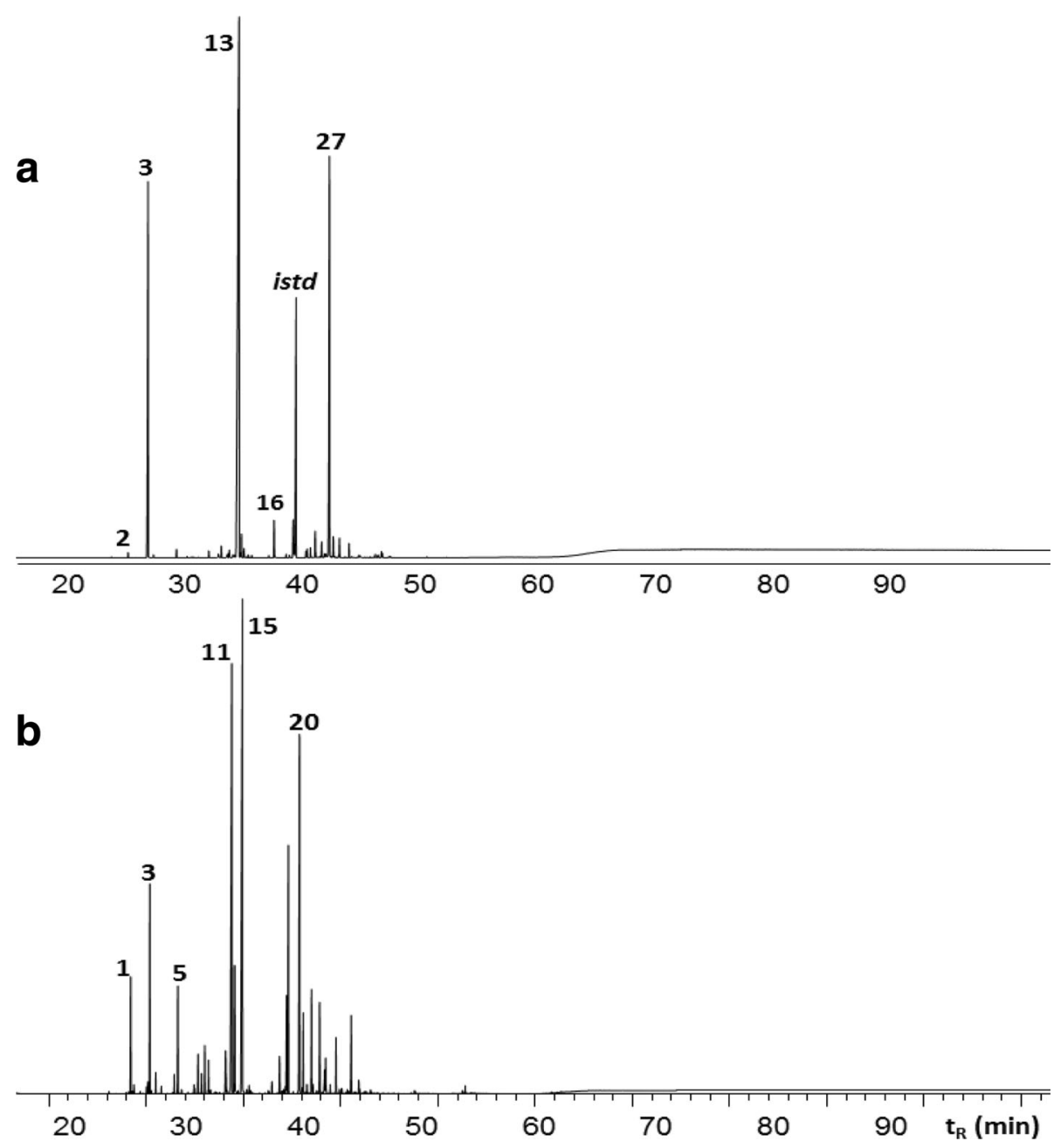

Fig. 1 Typical gas chromatography-mass spectrometry (GC-MS) profiles, in a DB-5 (60 m) column with a mass selective detector (El. $70 \mathrm{eV}$ ), of essential oils obtained from Lippia alba Carvone (a) and Citral (b) chemotypes by microwave-assisted hydrodistillation (MWHD). The corresponding peak identification is showed in Table 2

\section{Terpene pharmacological interactions on $T$. cruzi}

Because D (+) limonene demonstrated the best performance as a selective trypanocidal agent on all the evolutionary forms of T. cruzi, this monoterpene was selected as a fixed-compound of a pharmacological interaction matrix among terpenes and BNZ. This matrix was assembled taking the $\mathrm{IC}_{50}$ values determined previously (Table 5). Following the FIC value interpretation described by Azeredo and Soares, (2013) [31], all the evaluated interactions were found to be synergic on both extra and intracellular forms of the parasite (except limonene with carvone, with $\Sigma \mathrm{FIC}=1.10$ and 1.04, on Epi and Tryp, respectively) (Table 6). Figure 3 shows these pharmacological relations as isobolograms of the mean FIC of each combination. The highest synergy was exhibited by limonene/BNZ combinations (Epi: $\Sigma F I C=0.44$; Tryp: $\Sigma F I C=0.42$; Amas: $\Sigma F I C=0.58$ ) (Table 6, Fig. 3), with the best trypanocidal performance achieved by the
$4 x C_{50}$ limonene: $1 / 2 \mathrm{IC}_{50} \mathrm{BNZ}$ mixture (4 times $\mathrm{IC}_{50}$ limonene plus one half of the $\mathrm{IC}_{50}$ of $\mathrm{BNZ}$ ), which reduced by

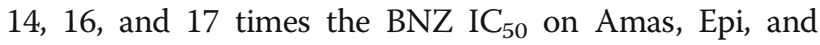
Tryp, respectively. Despite its good performance, this combination also resulted in an increased cytotoxicity on Vero cells $(\Sigma F I C=0.54)$. On the other hand, limonene with caryophyllene oxide represented the second-best combination by anti-parasitic efficacy (Epi $\Sigma$ FIC $=0.49$; Tryp $\Sigma$ FIC $=0.45$; and Amas $\Sigma$ FIC $=0.71$ ), while offering an additional advantage of reduction of the individual cytotoxicity of each terpene on Vero cells $(\Sigma \mathrm{FIC}=1.22)$ (Table 6, Fig. 3).

\section{Morphological analysis on $T$. cruzi forms}

The morphological changes induced by the treatments studied (EOs, terpenes, or BNZ, and their combinations) were analyzed by optical and fluorescent microscopy using phase contrast, and nuclear specific (DAPI) and 
Table 2 Peak assignment for GC-MS profiles of essential oils extracted by microwave-assisted hydrodistillation (MWHD) from Lippia alba Carvone (A) and Citral (B) chemotypes plants growing in Bucaramanga (Colombia)

\begin{tabular}{|c|c|c|c|c|c|}
\hline \multirow[t]{2}{*}{ Peak } & \multirow[t]{2}{*}{ Compound } & \multicolumn{2}{|l|}{ LRI } & \multicolumn{2}{|c|}{ Relative Quantity, \% } \\
\hline & & $\overline{\mathrm{DB}-5 \mathrm{MS}^{a}}$ & DB-WAX & Carvone (A) & Citral (B) \\
\hline 1 & 6-Methyl-5-hepten-2-one & 986 & 1241 & - & 3.3 \\
\hline 2 & $\beta$-Myrcene & 991 & 1064 & 0.8 & - \\
\hline 3 & Limonene & 1034 & 1105 & 29.1 & 6.6 \\
\hline 4 & trans- $\beta$-Ocimene & 1047 & 1153 & 0.7 & 0.2 \\
\hline 5 & Linalool & 1100 & 1453 & 0.6 & 1.9 \\
\hline 6 & Citronellal & 1154 & 1381 & - & 1.1 \\
\hline 7 & Borneol & 1181 & 1613 & 0.8 & - \\
\hline 8 & cis-Dihydrocarvone & 1203 & 1517 & 0.2 & - \\
\hline 9 & trans-Dihydrocarvone & 1211 & 1537 & 0.2 & - \\
\hline 10 & Nerol & 1231 & 1708 & - & 0.8 \\
\hline 11 & Neral & 1248 & 1589 & - & 21.5 \\
\hline 12 & Geraniol & 1252 & 1755 & - & 5.6 \\
\hline 13 & Carvone & 1258 & 1653 & 35.0 & - \\
\hline 14 & Piperitone & 1264 & 1641 & 2.4 & - \\
\hline 15 & Geranial & 1275 & 1643 & - & 28.7 \\
\hline 16 & Piperitenone & 1349 & 1842 & 4.0 & - \\
\hline 17 & Geranyl Acetate & 1379 & 1662 & - & 1.5 \\
\hline 18 & $\beta$-Bourboneno & 1396 & 1428 & 1.2 & - \\
\hline 19 & $\beta$-Elemene & 1397 & 1496 & 1.0 & 3.0 \\
\hline 20 & trans- $\beta$-Caryophyllene & 1436 & 1506 & 0.2 & 12.1 \\
\hline 21 & $\beta$-Gurjunene & 1444 & 1447 & 0.2 & - \\
\hline 22 & a-Guaiene & 1447 & 1498 & - & 1.8 \\
\hline 23 & trans- $\beta$-Farnesene & 1456 & 1570 & 0.7 & - \\
\hline 24 & a-Humulene & 1471 & 1580 & 0.1 & 2.7 \\
\hline 25 & $\gamma$-Gurjunene & 1475 & 1587 & 0.4 & - \\
\hline 26 & Germacrene D & 1486 & 1552 & 0.1 & 2.6 \\
\hline 27 & Bicyclosesquiphellandrene & 1496 & 1624 & 8.2 & - \\
\hline 28 & Bicyclogermacrene & 1509 & 1608 & 0.5 & - \\
\hline 29 & a-Bulnesene & 1515 & 1627 & - & 1.4 \\
\hline 30 & Cubebol & 1528 & 1855 & 0.5 & - \\
\hline 31 & Germacrene-4-ol & 1591 & 1967 & 0.6 & - \\
\hline 32 & Caryophyllene Oxide & 1600 & 1909 & - & 2.3 \\
\hline
\end{tabular}

$L R I$ Linear retention index

a Linear Retention Index experimentally determined in DB-5MS (60 m) column

bLinear Retention Index experimentally determined in DB-WAX $(60 \mathrm{~m})$ column

mitochondrial membrane potential (Mitotracker Red CMXRos [35]) stains. As shown in Fig. 4, some of the tested treatments induced significant changes on parasitic morphology such as: spherical cell conformation, reduced cytoplasmic volume (Fig. 4a, DIC), mitochondrial membrane potential deplection (Fig. 4a, MitoTracker), and formation of a nuclear speckled/condensation pattern (Fig. 4a, DAPI). In one unique finding, the caryophyllene oxide treatment also caused a flagellum to be lost. Conversely, $T$. cruzi cells treated with BNZ displayed cellular edema and loss of cellular membrane integrity, but with conserved mitochondrial energetic potential (Fig. 4a). Under the same conditions, Vero host cells did not present visible morphological alterations (data not shown).

\section{DNA fragmentation}

A possible endonuclease activation triggered by studied compounds (oils, terpenes or their combinations) was 
Table 3 Relative chemical composition and anti-proliferative effect on T. cruzi of EOs extracted from the Citral chemotype of L. alba

\begin{tabular}{|c|c|c|c|c|c|c|c|c|c|c|c|c|c|c|c|c|}
\hline \multirow[t]{2}{*}{ Season } & \multirow[t]{2}{*}{ Material } & \multirow[t]{2}{*}{$\mathrm{EO}^{\mathrm{a}}$} & \multirow{2}{*}{$\begin{array}{l}\text { Extra }^{b} \\
\text { Time } \\
\min ^{c}\end{array}$} & \multirow{2}{*}{$\begin{array}{l}\text { Part } \\
\text { Plant }\end{array}$} & \multicolumn{5}{|c|}{ Chemical Composition } & \multicolumn{2}{|l|}{ Epif } & \multicolumn{2}{|l|}{ Tryp $^{j}$} & \multicolumn{2}{|l|}{ Amas $^{k}$} & \multirow{2}{*}{$\begin{array}{l}\text { Vero } \\
\mathrm{CC}_{50}{ }^{\prime} \pm \\
\mathrm{SD}^{\mathrm{h}} \mu \mathrm{g} / \mathrm{mL}\end{array}$} \\
\hline & & & & & $\begin{array}{l}\text { Neral } \\
\%\end{array}$ & $\begin{array}{l}\text { Geraniol } \\
\%\end{array}$ & $\begin{array}{l}\text { Geranial } \\
\%\end{array}$ & $\begin{array}{l}\text { Caryop }^{d} \\
\%\end{array}$ & $\begin{array}{l}\text { CarOx } \\
\%\end{array}$ & $\begin{array}{l}\mathrm{IC}_{50^{g}} \pm \\
S D^{h} \mu \mathrm{g} / \mathrm{mL}\end{array}$ & $\mathrm{SI}^{\mathrm{i}}$ & $\begin{array}{l}\mathrm{I}_{50^{g}} \mathrm{SD}^{\mathrm{h}} \\
\mu \mathrm{g} / \mathrm{mL}\end{array}$ & $\mathrm{SI}^{\mathrm{i}}$ & $\begin{array}{l}\mathrm{IC}_{50^{\mathrm{g}}} \pm \\
\mathrm{SD} \mathrm{D}^{\mathrm{h}} \mu \mathrm{g} / \mathrm{mL}\end{array}$ & $\mathrm{SI}$ & \\
\hline Dry & Dry & A28 & 45 & $\left.\operatorname{lnfl}\right|^{m}$ & 19.3 & 31.5 & 31.3 & 2.3 & - & $14 \pm 2.6$ & 7.1 & $31 \pm 1.9$ & 3.1 & $66 \pm 4.8$ & 1.5 & $97 \pm 11$ \\
\hline \multirow[t]{6}{*}{ Rainy } & Fresh & A25 & 45 & $A L^{n}$ & 22.8 & 5.3 & 27.5 & 4.6 & 2.8 & $18 \pm 0.7$ & 5.3 & $19.4 \pm 0.9$ & 4.9 & $>33.3$ & $N D^{r}$ & $95 \pm 9.2$ \\
\hline & \multirow[t]{5}{*}{ Dry } & $\mathrm{A} 13$ & 30 & $Y L^{\circ}$ & 30.6 & - & 54.5 & 2.9 & - & $17 \pm 1.7$ & 7.0 & $21 \pm 1.6$ & 5.7 & $88 \pm 5.4$ & 1.4 & $121 \pm 10.1$ \\
\hline & & $\mathrm{A} 20$ & 30 & $\mathrm{ML}^{\mathrm{p}}$ & 32.1 & - & 54 & 4 & 2.4 & $9 \pm 1.2$ & 7.8 & $14 \pm 0.9$ & 4.7 & $>33.3$ & ND & $66 \pm 5.9$ \\
\hline & & A23 & 90 & $M L$ & 28 & - & 37.8 & 6.8 & 2.9 & $8 \pm 1.3$ & 6.2 & $17 \pm 1.3$ & 3.0 & $>33.3$ & ND & $51 \pm 6.2$ \\
\hline & & A24 & 90 & $M L$ & 24 & - & 34.3 & 2 & 5.7 & $16 \pm 1.6$ & 5.7 & $29 \pm 1.8$ & 3.1 & $69 \pm 3.0$ & 1.3 & $91 \pm 7.1$ \\
\hline & & $B N Z^{\mathrm{a}}$ & - & - & - & - & - & - & - & $17 \pm 0.9$ & 8.2 & $1.2 \pm 0.1$ & 116.3 & $6 \pm 0.9$ & 22.4 & $139 \pm 2.3$ \\
\hline
\end{tabular}

${ }^{\mathrm{a}}$ EO Essential oil, ${ }^{\mathrm{b}}$ Extra Extraction, ${ }^{\mathrm{c}} \min$ Minutes, ${ }^{\mathrm{d}} \mathrm{Caryop}$ Caryophyllene, ${ }^{\mathrm{e}} \mathrm{CarOx}$ Caryophyllene oxide, ${ }^{\mathrm{f}}$ Epi Epimastigote, ${ }^{9} / C_{50}$ Inhibitory concentration 50 , 'SD Standard deviation, 'S/ Selectivity index $\left(\mathrm{CC}_{50} / \mathrm{IC}_{50}\right)$, ${ }^{\mathrm{j}}$ Tryp Trypomastigote, ${ }^{\mathrm{k}}$ Amas Amastigote, ${ }^{\prime} \mathrm{C} \mathrm{C}_{50}$ Cytotoxic concentration 50 , ${ }^{\mathrm{m}} / \mathrm{nfl}$ Inflorescences, ${ }^{\mathrm{n}} A L$ All leaves, ${ }^{\circ} Y L$ Young leaves, ${ }^{\mathrm{p}} M L$ Mature leaves, ${ }^{\mathrm{a}} B N Z$ Benznidazole, ${ }^{\mathrm{r}} N D$ Not determined

assessed through agarose gel DNA electrophoresis and TUNEL analyses. DNA degradation was observed by band disappearance in agarose gel (data not shown) and confirmed through green fluorescence on nuclei and kinetoplasts from Epi forms treated for $48 \mathrm{~h}$ with double doses at $\mathrm{IC}_{50}\left(2 \mathrm{xIC} \mathrm{C}_{50}\right)$ of limonene, caryophyllene oxide, and the mix limonene:BNZ; with percentages of 94, 99, and 98 , respectively (Fig. $4 \mathrm{~b}$ ). Non-significant fragmentation was observed on untreated Epi (Fig. 4b).

\section{Phosphatidylserine externalization}

A flow cytometry analysis was carried out to determine the general mechanism of cell death. As expected, untreated Epi showed high viability rates (99.7\%) (Fig. 5a), whereas the various terpene treatments $\left(48 \mathrm{~h}\right.$ at $\left.2 \mathrm{xIC}_{50}\right)$ caused high percentages of cell death, with 95.7, 89.2, 78.4, and 95.9\% for cayophyllene oxide, limonene, citral, and the combination limonene:BNZ, respectively $(p=0.0001)$. No treatment showed statistically significant levels of negative SYTOX + positive Annexin V $(p>0.05)$, except the apoptosis positive control (15 day-old parasite culture) (13.6\%) (Fig. 5f). On the other hand, all the treated cultures displayed high percentages of positive SYTOX and positive Annexin $\mathrm{V}$. These results suggest a possible trigger of a late apoptosis mechanism (Fig. 5).

\section{Discussion}

In Chagas Disease, the pathogen-specific treatments such as BNZ - should be prescribed for acute cases and for younger patients with little or no evidence of established cardiomyopathy [36, 37]. On the other hand, recent results from global trials have questioned the benefit of these therapies in chronic patients $[8,36]$. In the case of BNZ, the drug demonstrated a significant decrease of the circulating parasite load, but no substantial effect in the prevention of the clinical decline $[8,36]$. Therefore, most patients with advanced T. cruzi disease receive only symptomatic treatment for cardiomyopathy or digestive symptoms. This absence of an association between parasite clearance by BNZ and the clinical progression of heart disease has been ascribed to both the restricted activity of the treatment in the inflammatory and fibrotic cardiomyopathy lesions, as well as the irreversibility of this damage [36]. Thus, alternative

Table 4 Relative chemical composition and anti-proliferative effect on T. cruzi of EOs extracted from the Carvone chemotype of L. alba

\begin{tabular}{|c|c|c|c|c|c|c|c|c|c|c|c|c|c|c|c|}
\hline \multirow[t]{2}{*}{ Season } & \multirow[t]{2}{*}{ Material } & \multirow[t]{2}{*}{$\mathrm{EO}^{\mathrm{a}}$} & \multirow{2}{*}{$\begin{array}{l}\text { Extra } \\
\text { Time } \\
\min ^{c}\end{array}$} & \multirow{2}{*}{$\begin{array}{l}\text { Part } \\
\text { Plant }\end{array}$} & \multicolumn{3}{|c|}{ Chemical Composition } & \multicolumn{2}{|l|}{ Epi $^{f}$} & \multicolumn{2}{|c|}{ Tryp $^{j}$} & \multicolumn{2}{|c|}{ Amas $^{k}$} & \multicolumn{2}{|l|}{ Vero } \\
\hline & & & & & $\begin{array}{l}\text { Limonene } \\
\%\end{array}$ & $\begin{array}{l}\text { Carvone } \\
\%\end{array}$ & $\begin{array}{l}\text { Piper }^{d} \\
\%\end{array}$ & $\mathrm{BCE}^{\mathrm{e}} \%$ & $\begin{array}{l}\mathrm{IC}_{50}{ }^{\mathrm{g}} \pm \\
\mathrm{SD} \mathrm{D}^{\mathrm{h}} \mu \mathrm{g} / \mathrm{mL}\end{array}$ & $\overline{S I^{i}}$ & $\begin{array}{l}I_{50^{g} S^{h}} \\
\mu \mathrm{g} / \mathrm{mL}\end{array}$ & $\mathrm{SI}^{\mathrm{i}}$ & $\begin{array}{l}I_{50^{g}} \pm \\
S D^{h} \mu \mathrm{g} / \mathrm{mL}\end{array}$ & $\overline{\mathrm{SI}}$ & $\begin{array}{l}\mathrm{CC}_{50}^{\prime} \pm \\
\mathrm{SD}^{\mathrm{h}} \mu \mathrm{g} / \mathrm{mL}\end{array}$ \\
\hline Dry & Fresh & B7 & 30 & $A L^{m}$ & 19.3 & 31.5 & 31.3 & 2.3 & $81 \pm 2.4$ & 2.5 & $37 \pm 2.1$ & 5.5 & $>150$ & $N D^{\circ}$ & $203 \pm 7.5$ \\
\hline \multirow[t]{5}{*}{ Rainy } & Dry & $2 \mathrm{~B} 8$ & 90 & $Y L^{n}$ & 22.8 & 5.3 & 27.5 & 4.6 & $96 \pm 4.4$ & 1.9 & $47 \pm 3.8$ & 4.0 & $>150$ & ND & $186 \pm 11.7$ \\
\hline & Fresh & B16 & 90 & $A L$ & 30.6 & - & 54.5 & 2.9 & $97 \pm 3.2$ & 2.2 & $57 \pm 3.0$ & 3.8 & $>150$ & ND & $216 \pm 9.6$ \\
\hline & Dry & B37 & 30 & $Y L$ & 32.1 & - & 54 & 4 & $92 \pm 3.9$ & 2.1 & $43 \pm 1.8$ & 4.5 & $>150$ & ND & $196 \pm 18.2$ \\
\hline & Dry & 2B18 & 45 & $\mathrm{AL}$ & 28 & - & 37.8 & 6.8 & $86 \pm 4.8$ & 1.9 & $34 \pm 3.1$ & 4.9 & $>150$ & ND & $165 \pm 10.2$ \\
\hline & Dry & 2B19 & 90 & $\mathrm{AL}$ & 24 & - & 34.3 & 2 & $78 \pm 3.5$ & 2.9 & $51 \pm 1.4$ & 4.4 & $>150$ & ND & $226 \pm 8.5$ \\
\hline
\end{tabular}

${ }^{\mathrm{a}} E O$ Essential oil, ${ }^{\mathrm{b}}$ Extra Extraction, ${ }^{\mathrm{c}}$ min Minutes, ${ }^{\mathrm{d}}$ Piper Piperitenone, ${ }^{\mathrm{e}} B C E$ Bicyclosesquiphellandrene, ${ }^{\mathrm{f}}$ Epi Epimastigote, ${ }^{\mathrm{g}} / C_{50}$ Inhibitory concentration $50 ;{ }^{\mathrm{h}} S D$ Standard deviation, 'SI Selectivity index $\left(C^{C} C_{50} / I C_{50}\right)$, ${ }^{j}$ Tryp Trypomastigote, ${ }^{\mathrm{k}}$ Amas Amastigote, ' $C C_{50}$ Cytotoxic concentration 50 , ${ }^{\mathrm{m}} A L$ All leaves, ${ }^{\mathrm{n}} Y L$ Young leaves, ${ }^{\circ} N D$ Not determined 

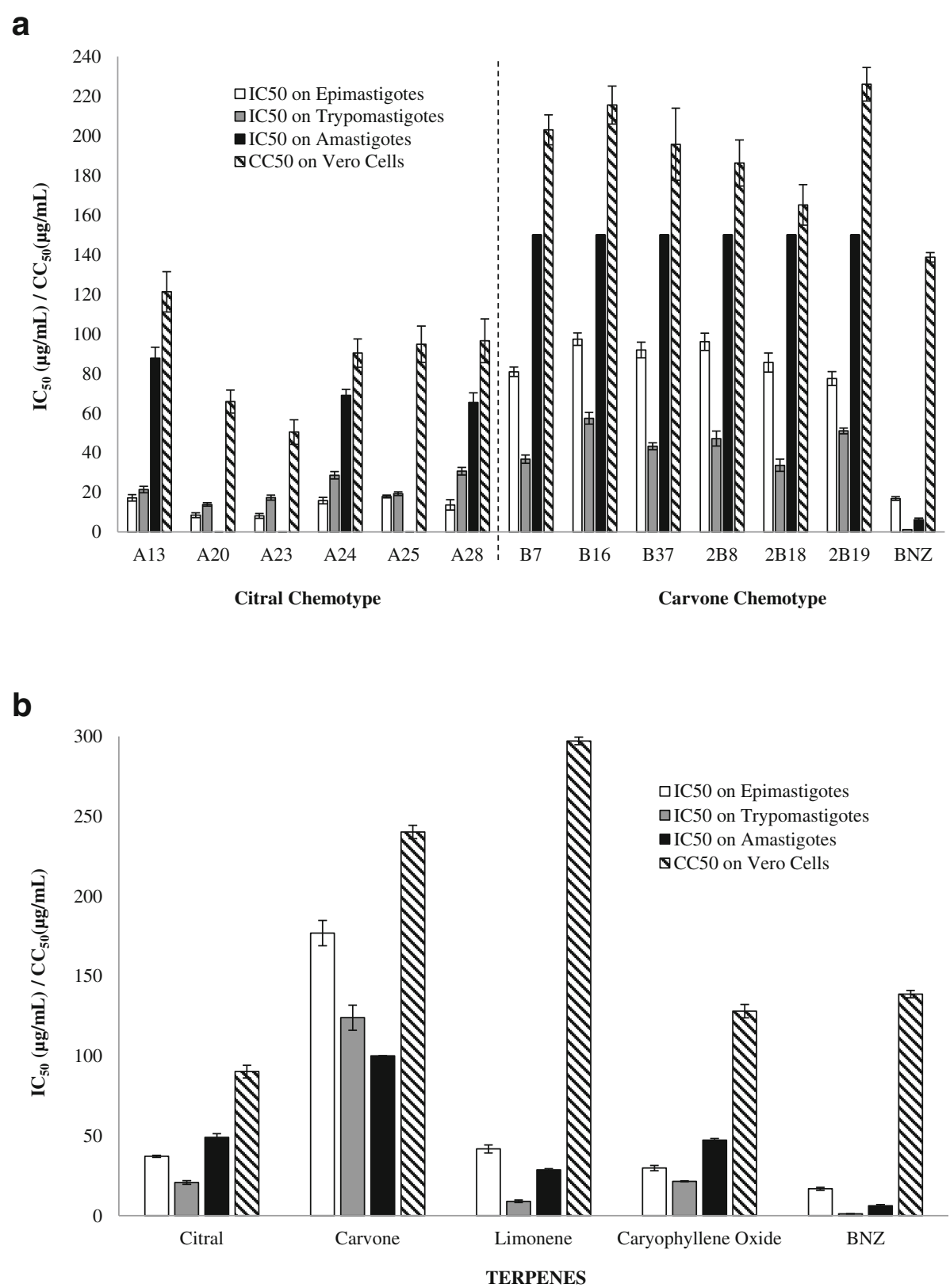

Fig. 2 In vitro trypanocidal and cytotoxic activity of Citral and Carvone chemotype L. alba essential oils (a) and their bioactive terpenes (b) on cyclic forms of Trypanosoma cruzi. $\mathrm{CC}_{50}$ : Inhibitory Concentration 50 on T. cruzi; $\mathrm{CC}_{50}$ : Cytotoxic Concentration 50 on Vero Cells

Table 5 Anti-parasitic effect on Trypanosoma cruzi of the major terpenes of Citral and Carvone chemotype L. alba essential oils

\begin{tabular}{|c|c|c|c|c|c|c|c|}
\hline Terpenes & $\mathrm{Epi}^{\mathrm{a}} \mid \mathrm{C}_{50}^{\mathrm{b}} \pm S \mathrm{SD}^{\mathrm{c}}(\mu \mathrm{g} / \mathrm{mL})$ & $\mathrm{SI}^{d}$ & $\operatorname{Tryp}^{\mathrm{e}} I \mathrm{C}_{50}{ }^{\mathrm{b}} \pm S \mathrm{SD}^{\mathrm{c}}(\mu \mathrm{g} / \mathrm{mL})$ & $\mathrm{SI}^{\mathrm{d}}$ & Amas $^{h} I C_{50}{ }^{b} \pm S D^{c}(\mu \mathrm{g} / \mathrm{mL})$ & $\mathrm{SI}^{\mathrm{d}}$ & Vero $\mathrm{CC}_{50}{ }^{\mathrm{i}} \pm \mathrm{SD}^{\mathrm{C}}(\mu \mathrm{g} / \mathrm{mL})$ \\
\hline $\mathrm{CarOx}^{j}$ & $30 \pm 1.7$ & 4.3 & $22 \pm 0.3$ & 5.9 & $47 \pm 1.0$ & 2.7 & $128 \pm 4.2$ \\
\hline Limonene & $42 \pm 2.5$ & 7.1 & $9 \pm 0.8$ & 32.8 & $29 \pm 0.7$ & 10.3 & $297 \pm 2.4$ \\
\hline Citral & $37 \pm 0.7$ & 2.4 & $21 \pm 1$ & 4.3 & $49 \pm 2.3$ & 1.8 & $90 \pm 3.9$ \\
\hline Carvone & $177 \pm 7.9$ & 1.4 & $124 \pm 8$ & 1.9 & $>100$ & $N D^{\prime}$ & $240 \pm 4.1$ \\
\hline$B N Z^{k}$ & $17 \pm 0.9$ & 8.2 & $1.2 \pm 0.1$ & 116.3 & $6.2 \pm 0.9$ & 22.4 & $139 \pm 2.3$ \\
\hline
\end{tabular}

${ }^{a}$ Epi Epimastigote, ${ }^{b} / C_{50}$ Inhibitory concentration $50,{ }^{c} S D$ Standard deviation, ${ }^{d} S /$ Selectivity index $\left(C C_{50} / I_{50}\right),{ }^{9} T r y p$ Trypomastigote, ${ }^{h} A m a s$ Amastigote, ${ }^{i} C C_{50}$ Cytotoxic concentration 50, ${ }^{\mathrm{j}} \mathrm{CarOx}$ Caryophyllene oxide, ${ }^{\mathrm{k}} B N Z$ Benznidazole, ${ }^{\mathrm{I}} \mathrm{ND}$ Not determinated 
Table 6 Pharmacological interactions among terpenes derived from L. alba

\begin{tabular}{|c|c|c|c|}
\hline Parasitic Form & Limonene + Compound & $\Sigma \mathrm{FIC}^{\mathrm{f}} \mu \mathrm{g} / \mathrm{mL} \pm \mathrm{SD}^{\mathrm{g}}$ & Pharmacological interaction \\
\hline \multirow[t]{4}{*}{$\overline{\mathrm{Epi}^{\mathrm{a}}}$} & $\mathrm{CarOx}^{\mathrm{d}}$ & $0.5 \pm 0.13$ & Synergism \\
\hline & Carvone & $1.1 \pm 0.08$ & Antagonism \\
\hline & Citral & $0.7 \pm 0.13$ & Synergism \\
\hline & $B N Z^{e}$ & $0.4 \pm 0.13$ & Synergism \\
\hline \multirow[t]{4}{*}{ Tryp } & $\mathrm{CarOx}^{\mathrm{d}}$ & $0.4 \pm 0.10$ & Synergism \\
\hline & Carvone & $1.04 \pm 0.04$ & Antagonism \\
\hline & Citral & $0.6 \pm 0.10$ & Synergism \\
\hline & $\mathrm{BNZ}$ & $0.4 \pm 0.10$ & Synergism \\
\hline \multirow[t]{4}{*}{ Amas $^{c}$} & CarOx ${ }^{d}$ & $0.7 \pm 0.23$ & Synergism \\
\hline & Carvone & $N D^{h}$ & $N D^{h}$ \\
\hline & Citral & $0.8 \pm 0.15$ & Synergism \\
\hline & $B N Z^{e}$ & $0.6 \pm 0.13$ & Synergism \\
\hline \multirow[t]{4}{*}{ Vero } & CarOx $x^{d}$ & $1.2 \pm 0.16$ & Antagonism \\
\hline & Carvone & $1.0 \pm 0.07$ & Additive \\
\hline & Citral & $1.0 \pm 0.07$ & Antagonism \\
\hline & $B N Z^{e}$ & $0.5 \pm 0.18$ & Synergism \\
\hline
\end{tabular}

${ }^{\mathrm{a}}$ Epi Epimastigote, ${ }^{\mathrm{b}}$ Tryp Trypomastigote, ${ }^{\mathrm{C}}$ Amas Amastigote, ${ }^{\mathrm{d}} \mathrm{CarOx}$ Caryophyllene oxide, ${ }^{\mathrm{e}} B N Z$ Benznidazole, ${ }^{\mathrm{f}} \mathrm{FIC}$ Fractional inhibitory concentration, ${ }^{\mathrm{g}} S D$ Standard deviation, ${ }^{\mathrm{h}} N D$ Not determinated

approaches for Chagas infection management should aim to control not only the parasite load, but also all the factors associated with cardiomyopathy progression (oxidative stress and immune effectors, among others) [36, 38].

Since parasitic protozoa are very sensitive to oxidative stress [39], the most common trypanocidal and anti-chagasic drugs like Nitroimidazoles derived (BNZ) and Nitrofurans (NFX) were developed based on their capability to induce Reactive Oxygen Species (ROS) production [40]. However, the clinical use of both medicines has been limited due to their high toxicity [41], mutagenic potential [42], the severity of their side effects $[38,41]$, and the lack of significant effects on clinical disease progression in the late stages of $T$. cruzi infection $[8,37]$.

In general, the development of new trypanocidal agents has been focused on the use of molecules that alter the cellular redox potential and take advantage of the scarce antioxidant defenses of the parasite $[39,40]$. A similar anti-protozoal effect has been described for essential oils rich in terpenes extracted from aromatic plants [43]. In this regard, EOs derived from Cymbopogon citratus showed promising results, with low $\mathrm{IC}_{50}$ values against $T$. cruzi $(15.5 \mu \mathrm{g} / \mathrm{mL}$ for Epi and Tryp; and $5.1 \mu \mathrm{g} / \mathrm{mL}$ for Amas) [17]. These trypanocidal effects were attributed to the high levels of the oxygenated monoterpene citral (a mixture of neral and geranial) [17]. Similar outcomes were obtained with oils extracted from a Colombian (Santander) variant of L. alba (Citral chemotype), which were rich in such terpenes as citral, geraniol, timol, and caryophyllene oxide [30].
In this work, we tested the trypanocidal and cytotoxic activity of 12 EOs, derived from two different plant chemotypes (Citral and Carvone) of L. alba, which were produced under controlled conditions of growth (geographic location, cultivation environment, and soil), plant parameters (age and part), material state (fresh or dry) and extraction conditions (time). These standardized procedures were prepared taking into consideration the recognized high phenotypical plasticity of the plant in response to genetic, environmental, and production parameters [25], which can induce significant variations in its EO constituents, as well as in their biological activities [25, 44].

In this regard, our results also confirmed significant differences in the major chemical compounds (terpenes), and trypanocidal activity of the L. alba oils produced under varying parameters (Tables 3 and 4, and Fig. 2a). While mixtures rich in citral and caryophyllene oxide (Citral chemotype EOs) achieved good performance on extracellular forms of $T$. cruzi (mean $\mathrm{IC}_{50}$ values of 13.6 and $21.9 \mu \mathrm{g} / \mathrm{mL}$ on Epi and Tryp, respectively) (Table 3); EOs of the same plant but rich in carvone and limonene (Carvone chemotype), displayed poor inhibitory results (mean $\mathrm{IC}_{50}$ values of 88.2 and $44.9 \mu \mathrm{g} / \mathrm{mL}$ for Epi and Tryp, respectively) (Table 4). Individual assays with a solution of citral consistently found that this compound caused an efficient arrest of the parasite's growth with $\mathrm{IC}_{50}$ values of 37.2 and $20.8 \mu \mathrm{g} / \mathrm{mL}$ on Epi and Tryp, respectively (Table 5 ).

With respect to citral, several studies on cancer and immune cell line models have demonstrated its interesting 

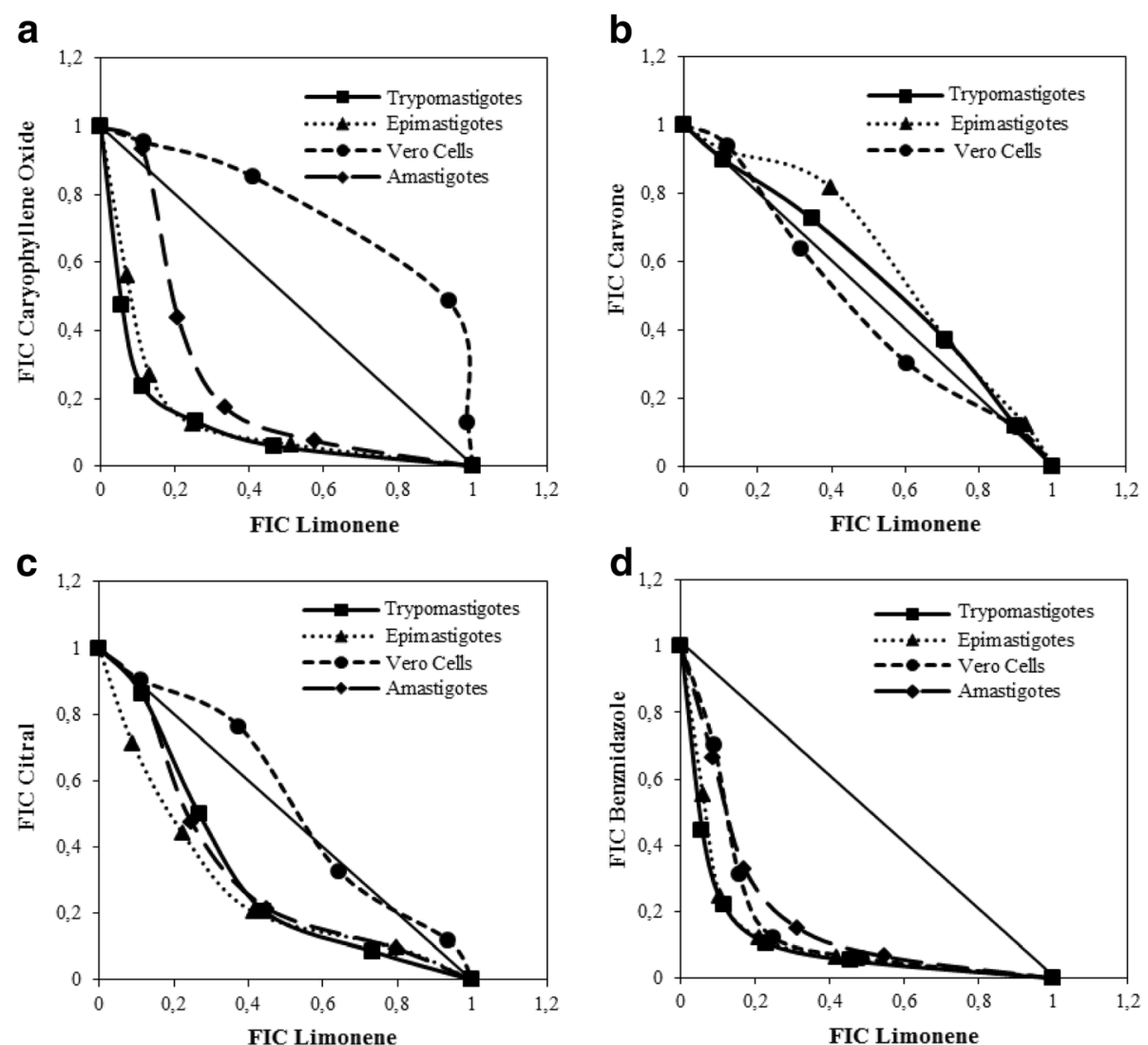

Fig. 3 Pharmacological interaction isobolograms among major terpenes of the Citral and Carvone chemotype L. alba essential oils: a limonene with caryophyllene oxide; $\mathbf{b}$ limonene with carvone; $\mathbf{c}$ limonene with citral; and $\mathbf{d}$ limonene with Benznidazole (BNZ). The interaction tests were performed on Epimastigotes, Trypomastigotes and Amastigotes of T. cruzi and Vero cells. Dotted lines correspond to an additive effect; points below, on, and above line indicate a synergistic, additive, and antagonistic effect, respectively

biological properties. As an anti-tumoral, this monoterpene exhibited significant anti-proliferative effects, in vitro and in vivo [45-48] and this cell growth inhibition was ascribed to the induction of mitochondrial apoptosis pathways (through p53 activation triggered by an ROS increase) [45]. In addition, citral has also been described as anti-inflammatory agent. In lipopolysaccharide (LPS)-stimulated macrophages, this terpene was found to suppress the expression of pro-inflammatory markers such as NLRP2 (NLR Family Pyrin Domain Containing 2), Interleukin (IL) 6 and IL-1 $\beta$ [24], Tumoral Necrosis Factor (TNF) $\alpha$ [49], as well as to activate the Peroxisome Proliferator-Activated Receptor (PPAR) $\gamma$ dependent-Cyclooxygenase 2 (COX2) promotor [50]. It is worth mentioning that over a range of different cells, the expression of COX2 is regulated in a variety of ways; playing an important role in tumoral genesis, inflammation, development, and circulatory homeostasis. In these activated macrophages, citral also blocks the genic expression of the LPS-induced Nitric Oxide Synthase (iNOS) [51] and, consequently, the production of Nitric Oxide (NO). It is thought that this inhibition could suppress transcriptional activation and the translocation of the nuclear factor-kappa
B (NF- B). These results suggest that citral is an anti-inflammatory agent whose effects could be associated with NF- B suppression [51], indicating that this compound may be a promising candidate for the treatment of inflammatory conditions like Chagas Disease.

Similarly, anticancer and anti-inflammatory properties have also been attributed to caryophyllene oxide, another major and bioactive constituent of Citral chemotype L. alba EOs. On human prostate and breast cancer cells, this sesquiterpene isolated from the EOs of medicinal plants such as guava (Psidium guajava), oregano (Origanum vulgare L.), cinammon (Cinnamomum spp.), clove (Eugenia caryophyllata), and black pepper (Piper nigrum L.), inhibited constitutive survival pathways (PI3K/AKT/mTOR/S6 K1) and ROS-dependent MAPK activation during tumorigenesis; triggering apoptosis on tumoral lineages and preventing inflammation, angiogenesis, and metastasis [52]. Furthermore, on stimulated primary splenocytes, caryophyllene oxide significantly increases the Th2/Th1 coefficient [22].

In our work, caryophyllene oxide was correlated with a trypanocidal effect, being found to be one of the major 

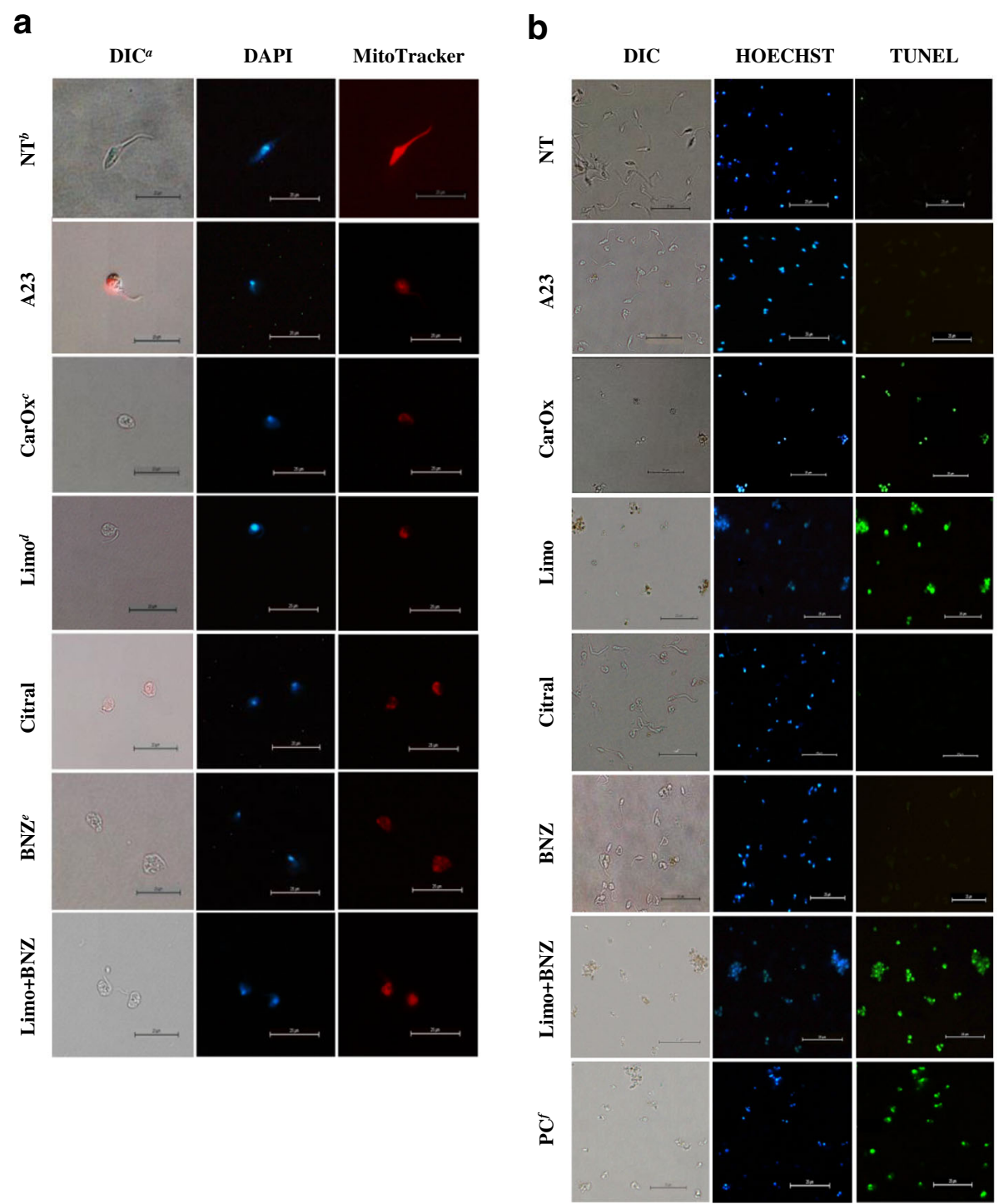

Fig. 4 Cell morphology changes of Trypanosoma cruzi by fluorescent and optical microscopy. a Cell morphology, mitochondrial membrane potential, nuclear and kinetoplast DNA of T. cruzi epimastigotes after treatment with essential oils, terpenes, or BNZ. b DNA fragmentation analysis by TUNEL assay on T.cruzi epimastigotes treated with terpenes. The preserved parasitic DNA was visualized with a blue HOECHST fluorescent probe (negative TUNEL) and the free DNA strands were observed in green (positive TUNEL). ${ }^{a} \mathrm{DIC}$ : Differential Interference Contrast Microscopy; ${ }^{\mathrm{b}} \mathrm{NT}$ : No Treatment; ${ }^{\mathrm{C}} \mathrm{CarOx}$ : caryophyllene

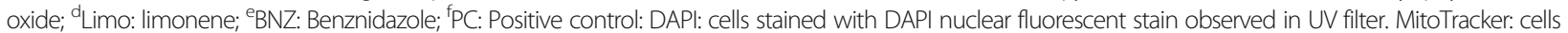
stained with MitoTracker Red CMXRos stain observed in an Excitation/Emission 579/599 (nm) filter. Photographs are representative of 10 observed fields

components of the most trypanocidal EOs studied: A23 and A20 (L. alba citral chemotype). Similarly, Cheikh Ali et al., [18], found a minimal lethal concentration of $0.1 \mu \mathrm{g} / \mathrm{mL}$ for EOs extracted from Aframomum sceptrum on cyclic forms of T. brucei; this trypanocidal action being associated with the presence of caryophyllene oxide. In the present study, this compound demonstrated a significant anti-proliferative effect against $T$. cruzi Epi $\left(\mathrm{IC}_{50}=29.8 \mu \mathrm{g} / \mathrm{mL}\right)$, Tryp $\left(\mathrm{IC}_{50}=21.6 \mu \mathrm{g} / \mathrm{mL}\right)$, and Amas $\left(\mathrm{IC}_{50}=47.4 \mu \mathrm{g} / \mathrm{mL}\right)$ (Table 5).

Another major $L$. alba terpene studied herein was limonene. This monoterpene is one of the main components of the Carvone chemotype oils. Due its beneficial pharmacological characteristics such as: low toxicity (used as food additive for decades) [53], high bioavailability [54], and selective anti-tumoral effect on a variety of cancer cell lines (leukemia, lymphoma, prostate, hepatic, colorectal, pancreatic, gastric, and breast, among others [54-57]); several research efforts have been undertaken with respect to this monoterpene. Interestingly, on a prostate cancer model, limonene caused apoptotic programmed cell death by the induction of a selective oxidative stress on tumoral cells [57]. As for protozoa, cancer cells are highly vulnerable to cell death induced by pro-oxidant agents (such as 

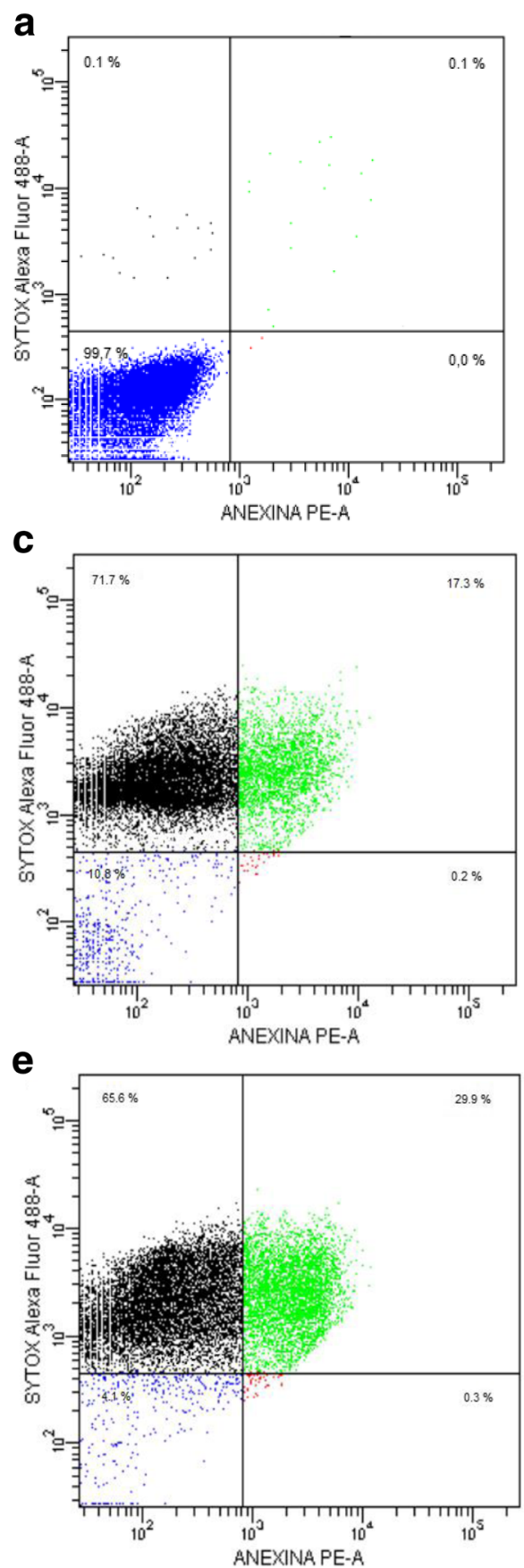
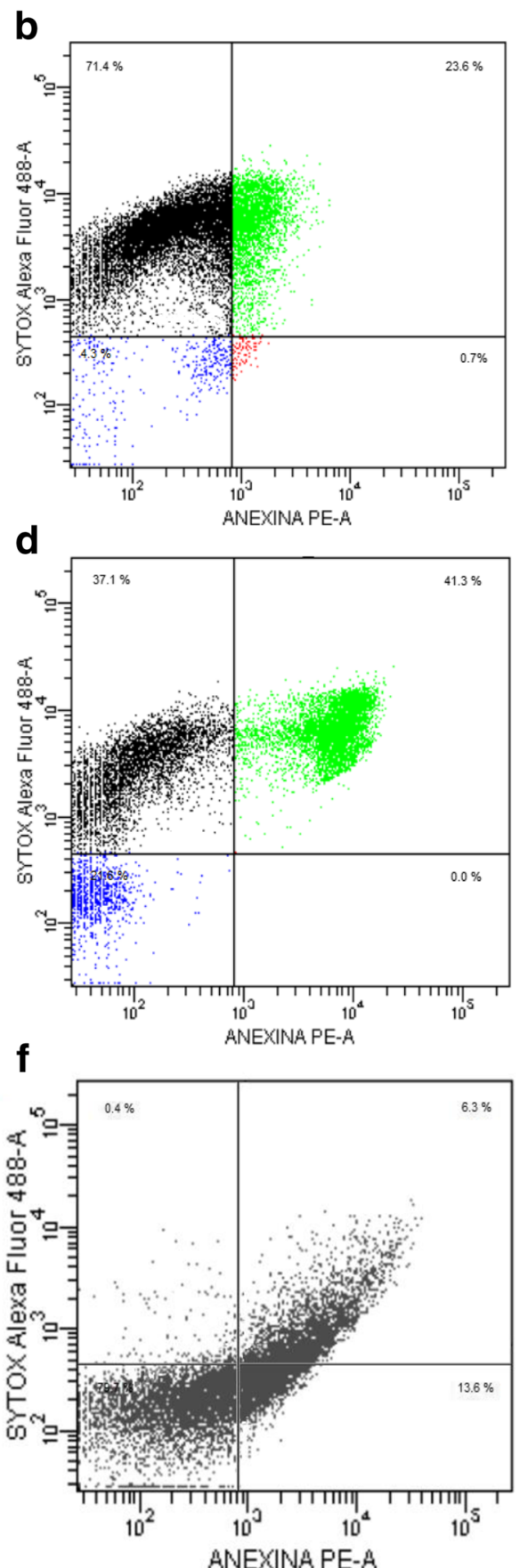

Fig. 5 Flow cytometry analysis of phosphatidylserine externalization of T. cruzi epimastigotes treated with terpenes or Benznidazole. a Negative control (untreated culture). b caryophyllene oxide; c limonene; d citral; e limonene:BNZ; and f apoptosis positive control (15 day-old parasite culture). The flow cytometry histograms are representative of two independent experiments

limonene) due their high metabolism and their deficient antioxidant mechanisms [58]. In this study, limonene was the best trypanocidal and most selective terpene with the lowest inhibitory doses $\left(\mathrm{IC}_{50}\right.$ of 9.0, 28.7, and $41.8 \mu \mathrm{g} / \mathrm{mL}$ on Tryp, Amas, and Epi, respectively). However, this good performance was not replicated when $T$. cruzi forms were treated with oils rich in carvone and limonene ( $L$. alba Carvone chemotype EOs displayed higher $\mathrm{IC}_{50}$ levels on Epi $=88.2 \mu \mathrm{g} / \mathrm{mL}$, Tryp $=44.9 \mu \mathrm{g} / \mathrm{mL}$, and Amas $>150 \mu \mathrm{g} / \mathrm{mL}$ ) (Table 5). Interestingly, carvone was the least effective trypanocidal terpene, with the lowest values of cell death percentage induction and 
highest $\mathrm{IC}_{50}$ results (Table 5). These results were associated with the strong antioxidant capability previously ascribed to this monoterpene [59]. Accordingly, a possible antagonism seems likely between limonene and carvone (which was present in the oil mixture in levels close to 42\%) (Table 4). Pharmacological interaction tests confirmed that the presence of carvone in the $L$. alba Carvone chemotype oils, impaired the limonene's trypanocidal performance on $T$. cruzi Tryp $(\Sigma$ CIF: $1.04 \mu \mathrm{g} / \mathrm{mL}$ ) and Epi ( $\Sigma$ CIF: $1.10 \mu \mathrm{g} / \mathrm{mL})$ forms (Table 6). In further assays, limonene presented a synergistic pharmacological interaction with the other bioactive $L$. alba terpenes (citral and caryophyllene oxide), and with BNZ, exhibiting $\Sigma$ FIC values $<0.8 \mu \mathrm{g} / \mathrm{mL}$ on the three parasite forms analyzed (Table 6). In combination with BNZ, limonene caused a significant decrease of the BNZ-IC ${ }_{50}$, by 14,16 , and 17 times on Amas, Epi, and Tryp, respectively (Table 6).

These positive interactions could have been due to the simultaneal action of these compounds on diverse and additive mechanisms that lead to cell death in susceptible lineages. Such mechanisms may include: a) polymerization microtubules disruption (citral) [60]; b) endoplasmic reticulum stress induction (citral) [60]; c) PIP3/AKT survival pathway inhibition (limonene, citral, and caryophyllene oxide) [52, 61, 62]; d) oxidative stress stimulation (limonene, citral, and caryophyllene oxide) [52, 57, 63]; and e) apoptosis by caspases activation (citral and limonene) [61-63], among others.

It is important to add that the parasite cells treated for $48 \mathrm{~h}$ with some of the studied compounds (A23 oil, citral, caryophyllene oxide, limonene, and the mixture of limonene and BNZ) evidenced typical characteristics of apoptosis, such as cytoplasmic blebbing, cell shrinkage, flagellum absence, loss of mitochondrial membrane potential, condensation of the nuclear chromatin, and DNA fragmentation (Fig. 4a). Also, the treatment of parasites with caryophyllene oxide or limonene (alone, in combination, or with BNZ) led to positive results in TUNEL assays (Fig. 4b). Correspondingly, an impairment of membrane potential (Fig. 4) and the externalization of phosphatidylserine (Fig. 5) were observed on T. cruzi cells treated with citral, limonene, and caryophyllene oxide. These results suggest a possible activation of an early apoptosis mechanism that rapidly progresses to late apoptosis (positive SYTOX plus positive Annexin V) accompanied by DNA fragmentation. In trypanosomatids like Leishmania donovani, T. brucei, and T. cruzi, these same characteristics have been reported in parasites suffering calcium imbalance and oxidative stress (by ROS) [64], mitochondrial enzyme knockdown [65], or treatment with sterols [66]. In these studies, the previously mentioned features were associated with a possible programmed cell death such as apoptosis or autophagy [67].
In an illness with a complex pathogenesis like Chagas Disease (which involves the parasitic persistence that triggers and sustains an anti-inflammatory immune response), the use of synergic drugs (like limonene/caryophyllene oxide) with several biological advantages (significant trypanocidal activity [32], low toxicity on mammal tissues [53]; and anti-genotoxic [68], chemoprotective [23], and anti-inflammatory activity [22]) could be an interesting platform for the development of an adjuvant therapy that enhances the therapeutic effects of the conventional treatments, principally in advanced stage of the infection (probably improving trypanocidal action, reducing therapeutic doses, increasing tolerance, or retarding resistance development) [69].

\section{Conclusions}

In this work, a range of growth, plant, and extraction parameters were found to significantly influence the chemical composition and trypanocidal activity of essential oils isolated from $L$. alba Citral and Carvone chemotypes. $L$. alba Citral chemotype oils, extracted under known and controlled conditions, presented significant trypanocidal activity on three cyclic $T$. cruzi forms: epimastigotes, trypomastigotes, and amastigotes. Assays using pure solutions of the main terpenes that constitute $L$. alba EOs, confirmed an association among parasitological activity and the presence of citral and caryophyllene oxide. Tests using EOs extracted from Carvone chemotype (rich in carvone and limonene), and their most important components, established an antagonistic relationship between carvone and limonene in their trypanocidal performance. Nevertheless, in this study, the best anti-T. cruzi, and most selective, activity was achieved by limonene. Citral, caryophyllene oxide, and limonene exhibited the induction of a possible apoptotic-like phenotype. In the synergistic interaction tests, limonene also improved the trypanocidal performance of citral, caryophyllene oxide, and even BNZ, on the three parasitic forms studied. The best synergic terpene activity was displayed by the limonene and caryophyllene oxide combination. These results should be confirmed by further pre-clinical studies and could be of interest for the development of alternative and adjuvant treatments improving the tolerance and parasitological efficacy, and broadening the spectrum of the effects, of the current conventional therapies for late phases of Chagas Disease. In such research, $L$. alba EOs represent a renewable source for commercial exploitation of these terpenes.

\section{Abbreviations}

IFIC: Sum FIC; AL: All Leaves; Amas: Amastigote; ANOVA: Analysis of variance; BCE: Bicyclosesquiphellandrene; BNZ: Benznidazole; CarOx: Caryophyllene

oxide; Caryop: Caryophyllene; $\mathrm{CC}_{50}$ : Cytotoxic Concentration 50; CDP: Cell death percentages; CENIVAM: National Research Center for

Agroindustrialization of Aromatic Medical and Tropical Species; COX2: Cyclooxygenase 2; DAPI: 4',6-diamidino-2-phenylindole; DMEM: Dulbecco's Modified Eagle's Medium; DMSO: Dimethyl sulfoxide; 
DNA: Deoxyribonucleic acid; EO: Essential oil; Epi: Epimastigotes; FBS: Inactivated Fetal Bovine Serum; FIC: Fractional Inhibitory Concentration; GC-MS: Gas chromatography coupled mass spectrometry; $\mathrm{I}_{50}$ : Inhibitory Concentration 50; LL: Interleukin; Inf: Inflorescences; iNOS: Induced Nitric Oxide Synthase; L. alba: Lippia alba; LIT: Liver Infusion Tryptose; LPS: Lipopolysaccharide; Min: Minutes; ML: Mature leaves; mm: Millimeter MWHD: Microwave-Assisted Hydrodistillation; ND: Not determined; NFKB: Nuclear factor-kappa B; NFX: Nifurtimox; NLRP2: NLR Family Pyrin Domain Containing 2; nm: Nanometer; NO: Nitric Oxide; NTD: Neglected Tropical Disease; OD: Optical Density; PBS: Phosphate Buffered Saline; Piper: Piperitenone; PPAR: Peroxisome Proliferator-Activated Receptor; ROS: Reactive species of oxygen; RPMl: Roswell Park Memorial Institute; SD: Standard deviation; SI: Selectivity index; T. brucei: Trypanosoma brucei; T. cruzi: Trypanosoma cruzi; TDC: Trypomastigotes Derived from Cells; TdT: Terminal desoxynucleotidyl Transferase; TNF: Tumor Necrosis Factor; Tryp: Trypomastigote; UTP: Uridine Triphosphate; YL: Young leaves

\section{Acknowledgements}

This study was supported by the Vicerrectoría de Investigaciones - Universidad de Santander, under grant 005-14; and the Vicerrectoría de Investigación y Extensión - Universidad Industrial de Santander, under grant 5658. The authors would like to express their appreciation to Dr. Marcos López Casillas and to Dr. Wendy Grey Nieto Pérez for their support in flow cytometry assays; to Dr. Yamile Leonor Vargas for Benznidazole purification, and to Dr. Camilo Durán, Qm. Carlos Ramírez, and Qm. Yaride Pérez for their support during the collection and characterization of EO samples. We are grateful to Mr. Emile Blanchette for assistance in the proofreading of this study.

\section{Funding}

This research was supported by the Vicerrectoría de Investigaciones - Universidad de Santander, under grant 005-14; and the Vicerrectoría de Investigación y Extensión - Universidad Industrial de Santander, under grant 5658.

\section{Availability of data and materials}

There are no restrictions to the availability of any materials and data. The raw data are available to other researchers upon request.

\section{Authors' contributions}

LTG conceived the study, designed all the experiments, and reviewed all the results and findings. EMM performed and analyzed all the trypanocidal, cytotoxic, and cell death assays, carried out data collection and analysis, and wrote the manuscript. EES collected the plants, and extracted and chemically characterized the essential oils. SML participated in the trypanocidal, cytotoxic, and synergistic tests. All authors read, revised, and approved the final manuscript.

\section{Ethics approval and consent to participate}

Not applicable.

\section{Consent for publication}

Not applicable

\section{Competing interests}

The authors declare that they have no competing interests.

\section{Publisher's Note}

Springer Nature remains neutral with regard to jurisdictional claims in published maps and institutional affiliations.

\section{Author details}

'Infectious Disease Research Program, Universidad de Santander, 680006 Bucaramanga, Colombia. ${ }^{2}$ Bacteriology and Clinical Laboratory Program, Universidad de Santander, 680006 Bucaramanga, Colombia. ${ }^{3}$ National Research Center for Agroindustrialization of Aromatic Medical and Tropical Species (CENIVAM), Universidad Industrial de Santander, 680002 Bucaramanga, Colombia.
Received: 28 November 2017 Accepted: 18 July 2018

Published online: 27 July 2018

\section{References}

1. World Health Organization. Investing to Overcome the Global Impact of Neglected Tropical Diseases: $3^{\text {rd }}$ WHO Rep Neglect Trop D. 2015.

2. Robertson LJ, Devleesschauwer B, De Noya BA, González ON, Torgerson PR. Trypanosoma cruzi: time for international recognition as a foodborne parasite. PLoS Neglect Trop D. 2016;10(6):e0004656.

3. Hotez PJ, Dumonteil E, Heffernan MJ, Bottazzi ME. Innovation for the 'bottom 100 million': eliminating neglected tropical diseases in the Americas. In: Curtis N, Finn A, Pollard A, editors. Hot topics in infection and immunity in children IX advances in experimental medicine and biology. Springer: New York; 2013. p. 1-12.

4. Cruz Bermúdez HF, Moreno Collazos JE. Seroprevalencia de tamizaje de Chagas y factores asociados a coinfección en un banco de sangre de Colombia durante 2006-2011. Rev Med Risaralda. 2015;21(1):26-30.

5. Coura JR. The main sceneries of Chagas disease transmission. The vectors, blood and oral transmissions-a comprehensive review. Mem Inst Oswaldo Cruz. 2015:110(3):277-82.

6. Bustamante JM, Tarleton RL. Potential new clinical therapies for Chagas disease. Expert Rev Clin Pharmacol. 2014:7(3):317-25.

7. Bern C. Chagas' disease. N Engl J Med. 2015;373(5):456-66.

8. Morillo CA, Marin-Neto JA, Avezum A, Sosa-Estani S, Rassi A Jr, Rosas F, Guhl F. Randomized trial of benznidazole for chronic Chagas' cardiomyopathy. $\mathrm{N}$ Engl J Med. 2015;373(14):1295-306.

9. Rassi A, De Rezende JM. American trypanosomiasis (Chagas disease). Infect Dis Clin N Am. 2012;26(2):275-91.

10. Bonney KM, Engman DM. Autoimmune pathogenesis of Chagas heart disease: looking back, looking ahead. Am J Pathol. 2015;185(6):1537-47.

11. Rassi A Jr, Neto M, Antonio J, Rassi A. Chronic Chagas cardiomyopathy: a review of the main pathogenic mechanisms and the efficacy of aetiological treatment following the Benznidazole evaluation for interrupting Trypanosomiasis (BENEFIT) trial. Mem Inst Oswaldo Cruz. 2017;112(3):224-35.

12. Schmidt TJ, Khalid S, Romanha AJ, Alves T, Biavatti M, Brun R, et al. The potential of secondary metabolites from plants as drugs or leads against protozoan neglected diseases-part II. Curr Med Chem. 2012;19(14):2176-228.

13. Al-Snafi AE. Antiparasitic effects of medicinal plants (part 1)-a review. IOSR PHR. 2016a;6(10):51-66.

14. Raut JS, Karuppayil SM. A status review on the medicinal properties of essential oils. Ind Crop Prod J. 2014;62:250-64

15. Borges AR, De Albuquerque Aires JR, Higino TMM, De Medeiros MDGF, Citó AMDGL, Lopes JAD, De Figueiredo RCBQ. Trypanocidal and cytotoxic activities of essential oils from medicinal plants of northeast of Brazil. Exp Parasitol. 2012;132(2):123-8.

16. Al-Snafi AE. Antiparasitic, antiprotozoal, molluscicidal and insecticidal activity of medicinal plants (part 2)-plant based review. Sch Acad J Pharm. 2016b;5(6):194-207.

17. Santoro GF, Cardoso MG, Guimarães LGL, Freire JM, Soares MJ. Antiproliferative effect of the essential oil of Cymbopogon citratus (DC) Stapf (lemongrass) on intracellular amastigotes, bloodstream trypomastigotes and culture epimastigotes of Trypanosoma cruzi (Protozoa: Kinetoplastida). Parasitology. 2007;134(11):1649-56.

18. Cheikh Ali Z, Adiko M, Bouttier S, Bories C, Okpekon T, Poupon E, Champy P. Composition, and antimicrobial and remarkable antiprotozoal activities of the essential oil of rhizomes of Aframomum sceptrum K. Schum. (Zingiberaceae). Chem Biodivers. 2011;8(4):658-67.

19. Santos NN, Menezes LR, Dos Santos JA, Meira CS, Guimarhes ET, Soares MB, Costa EV. A new source of (R)-limonene and rotundifolone from leaves of Lippia pedunculosa (verbenaceae) and their trypanocidal properties. Nat Prod Commun. 2014;9(6):737-9.

20. Villamizar LH, Cardoso MDG, Andrade JD, Teixeira ML, Soares MJ. Linalool, a Piper aduncum essential oil component, has selective activity against Trypanosoma cruzi trypomastigote forms at $4^{\circ} \mathrm{C}$. Mem Inst Oswaldo Cruz. 2017;112(2):131-9.

21. Stashenko EE, Martínez JR, Durán DC, Córdoba Y, Caballero D. Estudio comparativo de la composición química y la actividad antioxidante de los aceites esenciales de algunas plantas del género Lippia (Verbenaceae) cultivadas en Colombia. Rev Acad Colomb Ci Exact Fís Nat. 2014:38:89-105.

22. Ku CM, Lin JY. Anti-inflammatory effects of 27 selected terpenoid compounds tested through modulating Th1/Th2 cytokine secretion profiles using murine primary splenocytes. Food Chem. 2013;141(2):1104-13. 
23. Bai J, Zheng Y, Wang G, Liu P. Protective effect of D-limonene against oxidative stress-induced cell damage in human lens epithelial cells via the p38 pathway. Oxidative Med Cell Longev. 2015;2016:1-12.

24. Liao PC, Yang TS, Chou JC, Chen J, Lee SC, Kuo YH, Ho LC, Chao LKP. Antiinflammatory activity of neral and geranial isolated from fruits of Litsea cubeba Lour. J Funct Foods. 2015;19:248-58.

25. García LT, Leal AF, Moreno ÉM, Stashenko EE, Arteaga HJ. Differential antiproliferative effect on K562 leukemia cells of Lippia alba (Verbenaceae) essential oils produced under diverse growing, collection and extraction conditions. Ind Crop Prod J. 2017;96:140-8.

26. Hennebelle T, Sahpaz S, Joseph H, Bailleul F. Ethnopharmacology of Lippia alba. J Ethnopharmacol. 2008;116(2):211-22.

27. Di Stasi LC, Oliveira GP, Carvalhaes MA, Queiroz-Junior M, Tien OS, Kakinami $\mathrm{SH}$, Reis MS. Medicinal plants popularly used in the Brazilian tropical Atlantic Forest. Fitoterapia. 2002;73(1):69-91.

28. Pinto EDPP, Amorozo MCDM, Furlan A. Conhecimento popular sobre plantas medicinais em comunidades rurais de mata atlântica-Itacaré, BA Brasil Acta bot bras. 2006;20(4):751-62.

29. Toscano GJ. Uso tradicional de plantas medicinales en la vereda San Isidro, municipio de San José de Pare-Boyacá: un estudio preliminar usando técnicas cuantitativas. Acta biol Colomb. 2006:11(2):1137-46.

30. Escobar P, Milena Leal S, Herrera LV, Martinez JR, Stashenko E. Chemical composition and antiprotozoal activities of Colombian Lippia spp essential oils and their major components. Mem Inst Oswaldo Cruz. 2010;105(2):184-90.

31. Azeredo CM, Soares MJ. Combination of the essential oil constituents citral, eugenol and thymol enhance their inhibitory effect on Crithidia fasciculata and Trypanosoma cruzi growth. Rev Bras Farmacogn. 2013;23(5):762-8.

32. Polanco-Hernández G, Escalante-Erosa F, García-Sosa K, Rosado ME, GuzmánMarín E, Acosta-Viana KY, Giménez-Turba A, Salamanca E, Peña-Rodríguez LM. Synergistic effect of lupenone and caryophyllene oxide against Trypanosoma cruzi. J Evid Based Complementary Altern Med. 2013;2013.

33. Adams R. Identification of essential oil components by gas chromatography / mass spectrometry. fourth ed. Illinois: Carol Stream; 2007. p. 804.

34. Fivelman QL, Adagu IS, Warhurst DC. Modified fixed-ratio isobologram method for studying in vitro interactions between atovaquone and proguanil or dihydroartemisinin against drug-resistant strains of Plasmodium falciparum. Antimicrob Agents Chemother. 2004;48(11):4097-102.

35. Pendergrass W, Wolf N, Poot M. Efficacy of MitoTracker green ${ }^{T M}$ and CMXrosamine to measure changes in mitochondrial membrane potentials in living cells and tissues. Cytom Part A. 2004;61(2):162-9.

36. Urbina JA. Recent clinical trials for the etiological treatment of chronic Chagas disease: advances, challenges and perspectives. J Eukariot Microbiol. 2015;62(1):149-56.

37. Malik LH, Singh GD, Amsterdam EA. The epidemiology, clinical manifestations, and management of chagas heart disease. Clin Cardiol. 2015;38(9):565-9.

38. Viotti R, De Noya BA, Araujo-Jorge T, Grijalva MJ, Guhl F, López MC, Torrico F. Towards a paradigm shift in the treatment of chronic Chagas disease. Antimicrob Agents Chemother. 2014;58(2):635-9.

39. Turrens JF. Oxidative stress and antioxidant defenses: a target for the treatment of diseases caused by parasitic protozoa. Mol Asp Med. 2004;25(1):211-20.

40. Wilkinson SR, Kelly JM. Trypanocidal drugs: mechanisms, resistance and new targets. Expert Rev Mol Med. 2009;11:e31.

41. Molina I, Salvador F, Sanchez-Montalva A, Treviño B, Serre N, Sao Avilés A, Almirante B. Toxic profile of benznidazole in patients with chronic Chagas disease: risk factors and comparison of the product from two different manufacturers. Antimicrob Agents Chemother. 2015:59(10):6125-31.

42. Rajao MA, Furtado C, Alves CL, Passos Silva DG, Moura MB, Schamber Reis BL, Mendes IC. Unveiling Benznidazole's mechanism of action through overexpression of DNA repair proteins in Trypanosoma cruzi. Environ Mol Mutagen. 2014;55(4):309-21.

43. Kpoviessi S, Bero J, Agbani P, Gbaguidi F, Kpadonou-Kpoviessi B, Sinsin B, Quetin-Leclercq J. Chemical composition, cytotoxicity and in vitro antitrypanosomal and antiplasmodial activity of the essential oils of four Cymbopogon species from Benin. J Ethnopharmacol. 2014;151(1):652-9.

44. Teles S, Pereira JA, Santos CH, Menezes RV, Malheiro R, Lucchese AM, Silva F. Geographical origin and drying methodology may affect the essential oil of Lippia alba (mill) NE Brown. Ind Crop Prod. 2012;37(1):247-52.

45. Liu Y, Whelan RJ, Pattnaik BR, Ludwig K, Subudhi E, Rowland H, Felder M. Terpenoids from Zingiber officinale (ginger) induce apoptosis in endometrial cancer cells through the activation of p53. PLoS One. 2012;7(12):e53178.
46. Dudai N, Weinstein Y, Krup M, Rabinski T, Ofir R. Citral is a new inducer of caspase-3 in tumor cell lines. Planta Med. 2005;71(05):484-8.

47. Zeng S, Kapur A, Patankar MS, Xiong MP. Formulation, characterization, and antitumor properties of trans-and cis-citral in the 4T1 breast cancer xenograft mouse model. Pharm Res. 2015;32(8):2548-58.

48. Mesa-Arango AC, Montiel-Ramos J, Zapata B, Durán C, Betancur-Galvis L, Stashenko E. Citral and carvone chemotypes from the essential oils of Colombian Lippia alba (mill.) NE Brown: composition, cytotoxicity and antifungal activity. Mem Inst Oswaldo Cruz. 2009;104(6):878-84

49. De Paula PM, Da Silva GN, Luperini BCO, Bachiega TF, De Castro Marcondes JP, Sforcin JM, Salvadori DMF. Citral and eugenol modulate DNA damage and pro-inflammatory mediator genes in murine peritoneal macrophages. Mol Biol Rep. 2014;41(11):7043-51.

50. Katsukawa M, Nakata R, Takizawa Y, Hori K, Takahashi S, Inoue H. Citral, a component of lemongrass oil, activates PPARa and $\gamma$ and suppresses COX-2 expression. BBA-Mol Cell Biol Lipid. 2010;1801(11):1214-20.

51. Lee HJ, Jeong HS, Kim DJ, Noh YH, Yuk DY, Hong JT. Inhibitory effect of citral on NO production by suppression of iNOS expression and NF-KB activation in RAW264. 7 cells. Arch Pharm Res. 2008;31(3):342-9.

52. Park KR, Nam D, Yun HM, Lee SG, Jang HJ, Sethi G, Ahn KS. $\beta$-Caryophyllene oxide inhibits growth and induces apoptosis through the suppression of $\mathrm{PI} 3 \mathrm{~K} / \mathrm{AKT} / \mathrm{mTOR} / \mathrm{S} 6 \mathrm{~K} 1$ pathways and ROS-mediated MAPKs activation. Cancer Lett. 2011;312(2):178-88.

53. Sun J. D-limonene: safety and clinical applications. Altern Med Rev. 2007:12(3):259.

54. Xiu-zhen WLZ. Growth inhibition effects of D-limonene on human gastric carcinoma MGC803 cells. Life Sci Instrum. 2009:1:012

55. Kapoor S. D-limonene: an emerging antineoplastic agent. Hum Exp Toxicol. 2013;32(11):1228.

56. Miller JA, Lang JE, Ley M, Nagle R, Hsu CH, Thompson PA, Chow HS. Human breast tissue disposition and bioactivity of limonene in women with earlystage breast cancer. Cancer Prev Res. 2013;6(6):577-84

57. Rabi T, Bishayee A. D-limonene sensitizes docetaxel-induced cytotoxicity in human prostate cancer cells: generation of reactive oxygen species and induction of apoptosis. J Carcinog. 2009;8:9.

58. Trachootham D, Zhou Y, Zhang H, Demizu Y, Chen Z, Pelicano H, et al. Selective killing of oncogenically transformed cells through a ROS-mediated mechanism by $\beta$-phenylethyl isothiocyanate. Cancer Cell. 2006;10(3):241-52.

59. Stashenko EE, Jaramillo BE, Martínez JR. Comparison of different extraction methods for the analysis of volatile secondary metabolites of Lippia alba (mill.) NE Brown, grown in Colombia, and evaluation of its in vitro antioxidant activity. J Chromatogr A. 2004;1025(1):93-103.

60. Chaimovitsh D, Altshuler O, Belausov E, Abu Abied M, Rubin B, Sadot E, Dudai $N$. The relative effect of citral on mitotic microtubules in wheat roots and BY2 cells. Plant Biol. 2012;14(2):354-64.

61. Jia SS, Xi GP, Zhang $M$, Chen YB, Lei B, Dong XS, Yang YM. Induction of apoptosis by D-limonene is mediated by inactivation of Akt in LS174T human colon cancer cells. Oncol Rep. 2013;29(1):349-54.

62. Xia $\mathrm{H}$, Liang $\mathrm{W}$, Song $\mathrm{Q}$, Chen $\mathrm{X}$, Chen $\mathrm{X}$, Hong J. The in vitro study of apoptosis in NB4 cell induced by citral. Cytotechnology. 2013;65(1):49-57.

63. Kapur A, Felder M, Fass L, Kaur J, Czarnecki A, Rathi K, Patankar M. The monoterpene, citral, increases intracellular oxygen radicals and inhibits cancer cell proliferation by inducing apoptosis and endoplasmic reticulum stress. Clin Cancer Res. 2016;615(22):19106-4404.

64. Das R, Roy A, Dutta N, Majumder HK. Reactive oxygen species and imbalance of calcium homeostasis contributes to curcumin induced programmed cell death in Leishmania donovani. Apoptosis. 2008;13(7):867-82.

65. García LT, Leite NR, Alfonzo JD, Thiemann OH. Effects of Trypanosoma brucei tryptophanyl-tRNA synthetases silencing by RNA interference. Mem Inst Oswaldo Cruz. 2007;102(6):757-62.

66. Menna-Barreto RF, Salomão K, Dantas AP, Santa-Rita RM, Soares MJ, Barbosa HS, De Castro SL. Different cell death pathways induced by drugs in Trypanosoma cruzi: an ultrastructural study. Micron. 2009;40(2):157-68.

67. Jimenez V, Paredes R, Sosa MA, Galanti N. Natural programmed cell death in T. cruzi epimastigotes maintained in axenic cultures. J Cell Biochem. 2008;105(3):688-98.

68. López MA, Stashenko EE, Fuentes JL. Chemical composition and antigenotoxic properties of Lippia alba essential oils. Genet Biol Mol. 2011;34(3):479-88

69. Chou TC. Theoretical basis, experimental design, and computerized simulation of synergism and antagonism in drug combination studies. Pharmacol Rev. 2006:58(3):621-81. 